\title{
Functional cardiac tissue engineering
}

\author{
Brian Liau, Donghui Zhang, and Nenad Bursac* \\ Department of Biomedical Engineering, Faculty of Cardiology, Duke University, Room 136 \\ Hudson Hall, Durham, NC 27708, USA
}

\begin{abstract}
Heart attack remains the leading cause of death in both men and women worldwide. Stem cellbased therapies, including the use of engineered cardiac tissues, have the potential to treat the massive cell loss and pathological remodeling resulting from heart attack. Specifically, embryonic and induced pluripotent stem cells are a promising source for generation of therapeutically relevant numbers of functional cardiomyocytes and engineering of cardiac tissues in vitro. This review will describe methodologies for successful differentiation of pluripotent stem cells towards the cardiovascular cell lineages as they pertain to the field of cardiac tissue engineering. The emphasis will be placed on comparing the functional maturation in engineered cardiac tissues and developing heart and on methods to quantify cardiac electrical and mechanical function at different spatial scales.
\end{abstract}

\section{Keywords}

action potential conduction; contractile force; stem cell; tissue cardiomyoplasty

Myocardial infarction due to coronary artery occlusion usually results in significant loss of working cardiomyocytes, pathological heart remodeling and heart failure. Approximately 1.3 million Americans suffer from myocardial infarction every year, and approximately 5.7 million are afflicted with heart failure, demonstrating the vital need for improved therapies [1]. In light of the limited efficacy of current drug and device treatments, as well as a severe shortage of heart donors, the implantation of exogenous cells has been proposed as an attractive solution to augment compromised heart function [2,3]. Due to its potential impact on the lives of millions of people worldwide, the field of cell-based cardiac therapy is rapidly moving forward with several clinical trials being in Phase II and Phase III, and more new trials starting each year [201].

While the outcomes of these trials have been modest but promising, it is now evident that the success of future cardiac cell therapies will be highly dependent on our ability to overcome the problem of low retention and survival of implanted cells [4,5]. Potential approaches to address this issue include: coinjecting cells with bioactive, in situ polymerizable hydrogels [6]; preconditioning cells with hypoxia or prosurvival factors [7]; genetic engineering of cells to enhance their angiogenic and/or antiapoptotic action [8,9]; and the epicardial implantation of a preassembled tissue-engineered patch [10,11]. In particular, tissue patch implantation, although surgically more complex than cell or cell/

(C) 2012 Future Medicine Ltd

*Author for correspondence: Tel.: +1 919660 5510, Fax: +1 919684 4488, nbursac@ duke.edu.

Financial \& competing interests disclosure

The authors have no other relevant affiliations or financial involvement with any organization or entity with a financial interest in or financial conflict with the subject matter or materials discussed in the manuscript apart from those disclosed. 
hydrogel injections, may support long-term survival of delivered cells and exert a more efficient structural and functional cardiac tissue reconstruction at the infarct site [12].

Traditionally, tissue-engineering approaches involve in vitro generation of structural and functional substitutes of native tissue with the use of one or more of the following: living cells, natural or synthetic materials (scaffolds), soluble or bound growth factors or tissue culture bioreactors [13]. In the case of cardiac tissue engineering, the loss of approximately 1 billion cardiomyocytes during infarction imposes large demand on the number of contractile muscle cells that would need to survive and integrate after implantation to exert sustained functional benefit. Skeletal myoblasts that can be readily obtained via biopsy and expanded in vitro have been the first autologous contractile cell source used to achieve this goal in clinics [14]. Recently, tissue-engineered patches composed of these cells have been shown to exert increased functional benefit over cell injections in animal studies $[15,16]$. As these cells do not electrically couple to cardiomyocytes [17], their therapeutic action relies on secretion of paracrine factors, including SDF-1, HGF and VEGF [16]. Recently, skeletal myoblast tissue patches generated by the cell sheet engineering approach pioneered by Okano's group have been implanted in a limited number of patients with dilated cardiomyopathy infarction [18]. The outcomes of these studies are awaiting future assessment [19].

In addition to skeletal myoblasts, multipotent adult stem cells from bone marrow, peripheral blood and heart have been used in several clinical trials for treatment of postinfarction disease $[20,21]$. Tissue patches generated from these cells have been applied in animal studies, where they have been shown to exert increased functional benefits compared with standard cell injections [12]. These benefits were attributed to enhanced survival, and consequently, paracrine action of implanted cells at the site of infarction. A small clinical trial of ten patients has also demonstrated the feasibility and safety of implanting collagenbased scaffolds seeded with bone marrow cells [22]. While most adult-derived stem cells, including bone marrow-, adipose- or cardiac-derived stem cells [23,24], can express cardiac markers under specific conditions in vitro, their potential to yield functional cardiomyocytes capable of generating action potentials and active contractions is significantly limited $[25,26]$. As such, these cells do not represent a viable cell source for functional cardiac tissue engineering. Nonetheless, due to their antiapoptotic, angiogenic, resident stem cellrecruiting and/or immuno modulatory paracrine actions, these cells may prove to be useful as supporting ('niche') cells to enhance engineered cardiac tissue survival, integration and function.

Ideally, stem cells with the potential to robustly attain a functional cardiac phenotype are expected to augment cardiac function through direct electromechanical coupling with host tissue. Currently, pluripotent stem cells, such as those derived from natural [27], parthenogenetic $[28,29]$ or somatic nuclear transfer [30] derived embryonic tissues (i.e., embryonic stem cells [ESCs]) or induced by transfection with pluripotency genes (i.e., induced pluripotent stem cells [iPSCs] [31,32]), present the most promising sources for generation of the large amounts of functional cardiomyocytes needed for tissue-engineering therapies. Unlike multipotent adult stem cells, pluripotent stem cells are theoretically capable of proliferating indefinitely, and can spontaneously differentiate into cells from any tissue or organ system in the body. They may therefore be able to generate the required quantity of cells for therapeutic interventions. In particular, ESCs can differentiate into an unequivocally cardiac functional phenotype, displaying action potential firing and spontaneous or induced contractile activity [33,34]. More recently, functional cardiomyocytes have been derived from human iPSCs (see Table 1) [35,36], raising the possibility of generating autologous cardiac tissue patches that would negate the risk of graft rejection and avoid potential ethical issues related to the use of ESCs. 
In this review, we will first summarize methods to derive and maintain pluripotent stem cell sources, such as ESCs and iPSCs, which are currently the most commonly utilized for cardiac tissue engineering, and describe protocols for their successful differentiation towards the cardiovascular lineages. This will be followed by an in-depth discussion of the current state of the cardiac tissue-engineering field, with an emphasis on the methods to rigorously assess engineered tissue function and relate it to normal cardiac development.

\section{Derivation \& maintenance of pluripotent stem cells}

\section{Pluripotent stem cells as a robust source of functional cardiomyocytes}

Different multipotent stem cell types have been assessed for their ability to differentiate into functional cardiomyocytes in vitro, either by use of different cytokines and synthetic small molecules, or by coculture with neonatal cardiomyocytes. These protocols often result in a fraction of cells $(<20 \%)$ expressing at least some cardiac markers, but these 'cardiac-like' cells typically have poor sarcomeric organization, low mitochondrial content and lack the ability to repeatedly contract or autonomously fire action potentials [37,38]. In contrast to multi potent stem cells, pluripotent stem cells such as ESCs and iPSCs have been repeatedly shown to differentiate into functional cardiomyocytes [7,33-35,39]. Relatively efficient cardiac differentiation protocols were originally derived for ESCs and directly applied to iPSCs, and range from the use of embryoid bodies to guided differentiation systems. Pluripotent stem cell-derived cardiomyocytes have been well-characterized, and typically exhibit polymorphic shape, well-organized sarcomeres, punctate membrane distribution of gap junctions and electromechanical properties that range from embryonic to neonatal levels of functionality [33-35,39]. At least in theory, existing differentiation protocols can be scaled up through the use of highly efficient directed differentiation approaches, as well as bioreactor technology, to generate therapeutically-relevant numbers of human cardiomyocytes [7,40-42].

\section{Derivation \& maintenance of ESCs \& iPSCs}

Similar to ESCs from other species, mouse ESCs are derived from the inner cell mass of the preimplantation blastocyst. These cells have traditionally been grown in colonies with characteristically smooth, rounded edges and refractile borders on top of a feeder layer of mitotically inactivated primary mouse embryonic fibroblasts (MEFs) [34]. The pluripotent state of mouse ESCs is maintained in the culture in the presence of LIF, which acts via the well-studied JAK-STAT3 pathway [43], and BMP-4 (present in fetal bovine serum), which acts via Smad induction of Id proteins [44]. A combination of these two cytokines allows for the self-renewal of mouse ESCs in feeder-free and serum-free conditions. Mouse ESCs have characteristic cell surface markers, which include SSEA-1, LIF receptor (CD118) and alkaline phosphatase [45]. Many different ESC lines exist, such as D3, E14 and TT2, which differ with respect to their potential for specific lineage commitment and germline contribution [46]. Mouse ESCs maintain a predominantly diploid, normal karyotype, even after multiple passages, making them invaluable tools for gene-targeting experiments where germline transmission is necessary.

Human ESCs differ from their mouse counterparts in several significant ways. They are positive for surface markers SSEA-3 and SSEA-4, TR1-60, TR1-81 and alkaline phosphatase, but are negative for SSEA-1 and CD118 [45]. Furthermore, human ESCs do not require LIF for the maintenance of pluripotency, as they do not express the LIF receptor and only weakly express gp130, both of which are vital trans membrane glycoproteins required for the activation of the JAK-STAT3 pathway by LIF [45]. Instead, pluripotency in human ESCs in maintained in a more complex and still incompletely understood fashion by bFGF. Recent work by Bendall et al. indicates that bFGF maintains human ESC 
pluripotency in an indirect manner, by inducing the secretion of IGF from human ESC fibroblast-like cells, which are often present in culture together with human ESCs. The secreted IGF then acts on human ESCs, maintaining their pluri potent state [47]. Until recently, mouse ESCs and human ESCs were thought to differ in a third way: mouse ESCs do not contribute to the formation of extraembryonic placenta in chimeric animals, and were therefore thought to be incapable of forming trophoblasts. Human ESCs, on the other hand, are known to be capable of differentiating into trophoblasts in the presence of BMP-4. A recent study has shown, however, that mouse ESCs may be capable of forming trophoblasts in a manner similar to human ESCs [48].

Many excellent reviews already cover the generation and maintenance of iPSCs from mice, humans and other species [49,50]. In seminar studies, the groups of Yamanaka and Thomson have shown that somatic cells from different tissues can be reverted to an induced pluripotent state by the overexpression of four transcription factors, namely $\operatorname{Oct} 3 / 4, \operatorname{Sox} 2$, Klf4 and $c-$ Myc [31,32,51], or Nanog and Lin28 substituted in place of Klf4 and $c-$ Myc [51]. A subset of these four factors can also be used to reprogram somatic cells, albeit at a reduced efficiency [52,53]. While the original methodologies used retro- or lenti-viruses to overexpress transcription factors, recent advances have enabled the generation of transgenefree iPSCs using episomal [54] or pig-gyBac plasmid vectors [55,56], mRNA delivery [57], adenoviruses [58] and the direct delivery or reprogramming proteins [59]. Once stable iPSC lines are derived, they can be maintained, passaged and differentiated towards cardiac and other lineages in the same way as ESCs.

\section{Derivation of cardiomyocytes \& cardiovascular progenitors from mouse ESCs}

Under the appropriate in vitro conditions, including suitable cell density and the presence of soluble induction factors, mouse ESCs undergo spontaneous differentiation to all three germ layers. This differentiation is commonly induced by: 3D aggregation in the form of embryoid bodies [60]; monolayer culture on a feeder of OP9 stromal cells [61]; monolayer culture on various extracellular matrix proteins [62]; or by directed differentiation of 2D monolayer cultures through the addition of defined factors such as activin-A, BMP-4, bFGF, VEGF-A and DKK-1 (see Table 2) [63]. During embryonic development, cells of the cardiovascular lineage arise out of the lateral plate mesoderm and migrate to form the primary and secondary heart fields [64]. Similarly, cardiac differentiation in vitro from ESCs proceeds in distinct stages, starting with the transient upregulation of mesodermal markers (Brachyury and MesP1) at day 4-5 of differentiation, followed by the expression of early cardiac markers Tbx-5, Gata-4, Nkx2.5 and Isl1 at differentiation day 6 [65-67]. At this stage, cardiac progenitor cells may still differentiate into vascular (smooth muscle and endothelial) cell lineages. From day 8 of differentiation, cardiac muscle markers such as amyosin heavy chain (a-MHC), myosin light chain (MLC), and the L-type calcium channel become significantly upregulated, coincident with the onset of spontaneous cell contractions [65].

Protocols to isolate spontaneously beating cardio myocytes have existed for many years. The simplest but most laborious and inefficient method involves plating the beating embryoid bodies on a gelatin-coated surface and performing microdissection of beating outgrowths. The purity of derived cardiomyocytes is highly operator-dependent [34] and can be improved to approximately $70 \%$ by Percoll gradient centrifugation [68].

ESCs can be isolated from transgenic mice where fluorescence reporter molecules (e.g., EGFP) are driven by cardiac-specific promoters and are used as a fluorescence-activated cell sorting (FACS) markers. Although high-purity cardiomyocytes can be obtained this way $(>98 \%)[69,70]$, FACS is known to be a relatively low-throughput and harsh process since it subjects cells to strong shearing forces. Alternatively, ESCs can be stably transfected in vitro 
to incorporate selection vectors such as antibiotic resistance genes. These purification methods result in greater purity (97-99\%) of selected cells (see Table 1). For example, Klug et al. stably transfected mouse ESCs with a fusion gene consisting of G418 resistance driven by an a-MHC promoter [71], which allowed the derivation of a $99 \%$ pure population of cardiomyocytes. This method has now been extended to allow for the isolation of cardiomyocytes at various stage of development by selecting for cells expressing Isl1, $\mathrm{Nkx} 2.5$, MLC-2V and the $\mathrm{Na}^{+} / \mathrm{Ca}^{2+}$ exchanger [60,66,67,69,72], yielding multi potent progenitors and pacemaker-, atrial- and ventricular-like cells. This method also scales up well and has been applied in rotating bioreactors [73] to allow the generation of large numbers of mouse cardiomyocytes.

Cardiovascular progenitors can also be isolated without genetic manipulation using cell sorting and extracellular labeling of specific membrane receptors such as Flk-1, PDGFR-a and CXCR-4 [74,75]. Similarly, tetramethylrhodamine methyl ester perchlorate, a live mitochondrial dye, was used in conjunction with FACS to obtain $>99 \%$ pure mouse ESCderived cardiomyocytes [76]. It remains to be seen if these methods can be scaled up to obtain the large numbers of healthy cardiomyocytes needed for cell and tissue-engineering therapies.

\section{Derivation of cardiomyocytes \& cardiovascular progenitors from human ESCs}

Despite the differences between human and mouse ESCs as described above, human ESCs behave in broadly similar ways to mouse ESCs in that they can be induced to differentiate into all three germ layers under favorable conditions. Human ESCs are typically differentiated to cardiomyocytes in one of three ways: as 3D aggregates in hanging droplets or suspension cultures $[33,39]$; by coculturing with visceral endodermal-like cell lines such as END-2 [77]; or by directed differentiation of 2D monolayer cultures through the sequential addition of defined factors such activin-A, BMP-4, bFGF, VEGF-A and DKK-1 (see Table 2) [7,40]. The percentage yield of cardiomyocytes is typically determined upon dissociation of embryoid bodies or monolayers by staining for cardiac-specific markers such as cardiac troponin T or $\beta$-MHC $[7,78,79]$. Most recently, work performed by Keller's and Elefanty and Stanley's groups has shown that cell surface marker SIRPA can be used to isolate cardiomyocytes and quantify their yield during a well-defined directed differentiation protocol $[79,80]$. However, this procedure may not be as effective for undirected embryoid body differentiation since SIRPA is also highly expressed in human lung and brain tissues.

One method to isolate human cardiomyocytes and cardiovascular progenitors from other differentiating cells is to use the microdissection and Percoll gradient centrifugation methods [68] described for mouse ESCs. On the other hand, compared with mouse ESCs, human ESCs are far less amenable to stable genetic manipulation due to a less efficient electroporation-mediated gene delivery, large variability among different cell lines, gene silencing during growth and passaging and poor clonal growth from single cells due to high sensitivity to their niche disruption [81]. As a result, relatively few studies have shown the successful purificaton of human cardio myocytes or cardiovascular progenitors using genetic selection methods. Huber et al., Anderson et al. and Kim et al. have shown that cardiomyocytes can be enriched by using G418 resistance driven by a-MHC or MLC-2v promoters, or alternatively by the negative selection of actively proliferating (noncardiomyocyte) cells via the herpes simplex virus type-1 thymidine kinase system [82-84]. Bu et al. and Elliott et al. have shown that multipotent cardiovascular progenitors can be isolated from human ESCs by using G418 resistance or $\beta$-galactosidase expression ( $\beta$-geo cassette) driven by the Isl-1 promoter, or alternatively by knock-in of eGFP at the Nkx2.5 locus [80,85]. The human VEGF receptor KDR, which is analogous to Flk-1 in mice, has been shown to allow the isolation of multipotent cardiac progenitors by fluorescence-activated cell sorting without the need for any genetic manipulation [40]. 
Finally, the cell surface antigen SSEA-1 has been shown to allow the isolation of a differentiating population of human ESCs that is responsive to the potent cardiogenic morphogen BMP-2. When induced with BMP-2, SSEA- $1^{+}$cells were found to attain early mesodermal and cardiogenic fate [86]. While difficult to prove, cardiac differentiation in vertebrates generally follows a conserved pattern, thus differentiation in human ESCs is expected to recapitulate some of the early stages of in vivo embryonic development, making it a potentially useful tool in developmental and toxicology studies [87].

\section{Pluripotent stem cell-based cardiac tissue engineering}

Several cardiac tissue-engineering methodologies have been developed for use with primary neonatal cardiomyocytes, and can be or have already been adapted for use with mouse, nonhuman primate and human ESCs or iPSCs (see Figure 1 and Table 3). These include: cell encapsulation in natural hydrogels to fabricate bundle-, ring-, pouch- or network-shaped tissue constructs [68,88-90]; cell seeding onto porous polymer foams, fibers or laser-drilled scaffolds to generate isotropic and anisotropic tissue patches [91-95]; self-assembly of cells into scaffold-free cell sheets or aggregated tissue constructs [96,97]; seeding of decellularized organs and tissues [98]; and use of in vivo tissue-engineering chambers clamped around arterivenous blood vessel loops [99]. Comprehensive reviews of the various tissue-engineering methodologies have been covered elsewhere [10,11]. In the following discussion, we will focus on studies that involved significant functional evaluation of engineered cardiac tissues derived from pluripotent stem cells (Table 3).

By using the engineered heart tissue (EHT) methodology developed by Zimmerman et al. [88], Guo et al. were the first to engineer cardiac tissue constructs derived from mouse ESCs [68]. Large numbers of D3 mouse ESCs were differentiated in slow-turning lateral vessels and purified for cardiomyocyte fractions using Percoll gradient centrifugation. The purified cardiomyocytes were then mixed with type I collagen and Matrigel ${ }^{\mathrm{TM}}$ (BD Biosciences, CA, USA), and cast in ring-shaped molds. After 5 days, the EHTs were subjected to mechanical conditioning for 1 week before functional testing. The obtained EHTs contained aligned and striated cardiomyocytes (and cells with neural and endothelial markers) and produced action potentials recorded by extracellular multielectrode arrays. Resulting active twitch forces of up to $70 \mu \mathrm{N}$ were inferior to those measured by Zimmerman et al. in EHTs made of neonatal rat ventricular myocytes [100]. The EHTs also showed physiological response to pharmaceutical stimuli such as isoproterenol and diltiazem.

Using a similar tissue-engineering strategy, Shimko et al. formed cardiac constructs using pure differentiated cardiomyocytes derived by genetic selection from D3 mouse ESCs with a neomycin-resistance gene driven by the a-MHC promoter [60]. They found that $10 \%$ cyclic stretch at rate of $1-3 \mathrm{~Hz}$ for 3 days increased the expression of cardiac markers such as acardiac actin, a-MHC and Mef-2c, but the resulting cardiac tissues were noncontractile. Immunostaining showed that pure cardiomyocytes were present, but they had disorganized sarcomeres and a relatively rounded appearance.

In a recent study by Okano's group, mouse ESCs clonally expressing a-MHC-NeoR were differentiated in spinner flasks and pure cardiomyocyte populations were obtained by selection with neomycin [97]. Cell sheets were formed by release of seeded cardiomyocyte monolayers from surfaces grafted with temperature sensitive poly( $N$-isopropylacrylamide). Intact cell sheets could be formed only if pure cardiomyocytes were mixed with 20-50\% neonatal mouse cardiac fibroblasts yielding synchronous contractions and action potential conduction. The two partially overlaid sheets synchronized their contractions, demonstrating the ability of electrical coupling. 
We have recently engineered highly functional cardiac tissue patches made of uniformly aligned and strongly coupled mouse ESC-derived cardiomyocytes and cardiovascular progenitors [89]. a-MHC-PuroR cardio myocytes were selected from differentiating embryoid bodies and encapsulated into network-shaped fibrin gel using a novel micromolding technique previously developed in our laboratory [101]. Similar to Okano's group, we found that functional cardiac tissue patches were only formed with the addition of a small percentage of primary neonatal rat cardiac fibroblasts. By contrast, when Nkx2.5puroR cardiovascular progenitors were selected using a similar method, they differentiated into both cardiomyocytes and vascular (smooth muscle and endothelial) cells, enabling the formation of functional tissue without the need for cardiac fibroblasts. Resulting tissue patches demonstrated unprecedented functional properties, supporting the conduction velocities of $22-25 \mathrm{~cm} / \mathrm{s}$ and generating contractile forces of up to $2 \mathrm{mN}$. This level of function is similar to that of engineered tissues produced using primary neonatal rat cardiomyocytes [100].

Although useful for in vitro studies of cardiac development and proof-of-concept implantation studies, mouse ESC-derived cardiac tissues are not suitable for clinical use. Caspi et al. were first to engineer human-based cardiac tissues by seeding porous poly-lactic co-glycolic acid scaffolds with human ESC-derived cardiomyocytes [91], human vascular endothelial cells (HUVECs) and MEFs. Histological ana lysis showed that the inclusion of embryonic fibroblasts caused HUVECs to condense into vascular structures within the bulk of the engineered tissue. The tissue constructs exhibited synchronous spontaneous beating and physio logical responses in response to chronotropic agents. Furthermore, cardiomyocytes displayed synchronous calcium transients over several cell lengths, which were disrupted by the gap junction uncoupler heptanol, suggesting the presence of functional gap junctions.

In a similar approach, Stevens et al. applied a directed differentiation of human ESCs to obtain relatively pure cardiomyocytes that were allowed to spontaneously aggregate with HUVECs and MEFs on an orbital shaker [96]. The resulting scaffold-free cardiac patches contracted synchronously in response to an externally applied electric field, exhibiting contractile amplitudes that decreased with increased stimulus frequency and became chaotic for frequencies above $3 \mathrm{~Hz}$. Cardiac tissue patches exhibited a passive stiffness of $7.9 \pm 3.1$ $\mathrm{mN} / \mathrm{mm}^{2}$, which was lower than that of human myocardium $\left(\sim 16 \mathrm{mN} / \mathrm{mm}^{2}\right.$ [102]). The patches also formed capillary structures in vitro and were capable of vascular integration with healthy host myocardium 1 week after implantation.

Recently, Tulloch et al. created cylindrical bundles composed of human ESC-derived cardiomyocytes and showed that both static and cyclic mechanical loading of the bundles enhanced cell alignment, while cyclic loading also promoted cardiomyocyte hypertrophy and proliferation [78]. The engineered tissue constructs produced maximum contractile forces of approximately $0.2-0.3 \mathrm{mN}$, yielding active stresses of $0.08 \mathrm{mN} / \mathrm{mm}^{2}$, which is two orders of magnitude lower than those measured in native human myocardium [103]. Mixing of cardiomyocytes with HUVECs and either human marrow stromal cells or MEFs promoted survival and vascular integration of cardiac bundles after implantation in healthy hearts of athymic rats. Increased purity of cardiomyocytes in the bundles (53\%, as judged by $\beta$-MHC staining) may further improve the functional output of these tissue constructs.

Currently, there is no defined methodology that would maximize the functional output of stem cell-derived engineered cardiac tissues, and in particular, it is unknown which parameter values optimized for neonatal rat cardiomyocytes can directly apply to stem cellderived cardiomyocytes. For example, two recent studies have shown that cardiac fibroblasts may be required for the formation of functional ESC-derived cardiac tissues [89,97], similar 
to what has been suggested for engineered tissues made of primary cardiac cells [104,105]. Interestingly, the above studies suggest the optimal ratio of cardiomyocytes to fibroblasts for functional cardiogenesis in vitro is still to be determined. Both studies suggest that even a small fibroblast fraction of approximately $10 \%$ (much less than in the adult heart) may still facilitate formation of a functional syncytium. On the other hand, although adding endothelial cells and embryonic fibroblasts or mesenchymal stem cells has been shown to enhance integration of engineered cardiac tissues with host myocardium [78,91,106], it is still not clear whether these cells yield functional improvements of the engineered muscle [78]. Based on the work of others and our own [80,85,89,107-109], cardiovascular progenitors (derived based on the activity of an Nkx2.5 enhancer element or Isl-1 promoter), which are able to differentiate in cardiomyocytes and an adequate fraction of supporting vascular cells, may represent an optimal source for functional cardiac tissue engineering. Alternatively, the addition of fibroblasts and/or endothelial cells to pure stem cell-derived cardiomyocytes may yield similar outcomes.

Furthermore, studies with neonatal rat cardiomyocytes have shown that, compared with use of rigid matrices, soft hydrogels offer advantages for cardiac tissue engineering by supporting macroscopic contractions and measurements of contractile force. The natural rather than synthetic hydrogels better support cardiomyocyte spreading and coupling by providing a much higher density of cell-adhesion sites; however, their batch-to-batch variability may preclude generation of tissues with highly reproducible function. Among different natural hydrogels, studies comparing type I collagen with fibrin gel suggest that fibrin is a superior scaffolding material [110] because it polymerizes faster than neutralized collagen, resulting in a more homogenous cell distribution within the engineered tissue. As a result, fibrin matrices are reportedly able to support a greater overall cell density, allowing engineered cardiac tissues to produce more contractile force [110].

Although applying electrical or mechanical stimulation has been shown to promote the function of engineered tissues derived from primary cardiomyocytes [105,111,112], comparatively little is known about the corresponding effects on stem cell-derived cardiac tissues. Sauer et al. and Serena et al. [113,114] have shown that electrical stimulation can increase the cardiac differentiation potential of mouse and human ESCs through the generation of intracellular reactive oxygen species, suggesting that electrical stimulation may also be beneficial to engineered tissue formation and function. Similarly, cyclic mechanical stimulation has been shown to enhance the proliferation and hypertrophy of human ESC-derived cardio myocytes in engineered tissues [78], and to improve the arrangement of cardiac sarcomeres and gap junctions in mouse ESC-derived constructs [60]. While these cellular effects would be expected to enhance the functional output of tissueengineered myocardium, no studies have yet reported direct evidence for this concept.

\section{Methods for functional assessment of stem cell-derived cardiomyocytes \& engineered cardiac tissues}

The therapeutic utility of stem cell-derived cardiomyocytes will eventually be determined by their functional properties, rather than the expression of cardiac markers. Thus, to provide safe and efficient electromechanical support for the failing heart, engineered cardiac tissues should be optimized and rigorously assessed for both single-cell and tissue-level functionality, including action potential characteristics, tissue-level electrical conduction and contractile force generation. 


\section{Patch clamp \& sharp microelectrode recordings of membrane currents \& potentials in individual cardiomyocytes}

Since its invention by Neher and Sakmann [115], the patch clamp techniques have become ubiquitous tools to probe electrophysiological properties of individual cells down to the single ion channel level. In the whole-cell configuration, the patch clamp technique is used to study the collective response of all ion channels within a cell membrane [116]. Usually, the large-bore patch clamp electrodes with resistances of 2-5 $\mathrm{m} \Omega$ are filled with a solution containing free ion concentrations similar to those inside a cell. A tight (gigaohm) seal is formed between the electrode and the cell membrane by suction, followed by a breakage of the membrane to make the intracellular space contiguous with the electrode solution. Different drugs, extracellular and intracellular ionic solutions and voltage-stepping protocols are applied to isolate and study the activity of specific membrane ion channels, pumps or exchangers. When the membrane patch is removed from the cell together with the electrode, it can be used to study the activity of single or small groups of ion channels. Two patch electrodes in whole-cell voltage mode can be simultaneously applied, one to each cell, to measure the degree of electrical coupling between the two cells [117]. Changes in membrane potential, including action potential generation, can be recorded either using whole-cell current clamp configurations or sharp microelectrodes with extremely narrow bores and resistances of 30-100 $\mathrm{m} \Omega$ [118]. The main advantages of sharp microelectrode recordings are the preservation of the true intracellular milieu and the ability to record action potentials from a cell within a network of coupled cells. On the other hand, unlike in patch clamp recordings, intracellular ion concentrations cannot be arbitrarily manipulated and ion channel currents cannot be recorded.

\section{Multielectrode arrays for the measurement of extracellular potentials \& conduction velocity}

Commercially available multielectrode arrays (MEAs) have become increasingly popular for millimeter-scale ana lysis of extracellular potential characteristics and propagation within beating clusters of mouse and human ESC- and iPSC-derived cardiomyocytes $[33,36,42,82,119]$. Recently, the MEA technology has been also adopted for use by pharmaceutical companies for high-throughput drug screening tests [120]. MEAs are planar arrays of small (20- $\mu \mathrm{m}$ diameter) electrodes spaced 100-200 $\mu \mathrm{m}$ apart on which cells can be cultured directly. Due to their proximity to the cultured cells, the electrodes are able to measure extracellular field potentials and can be used to assess spontaneous beating rate, changes in repolarization characteristics and conduction path and velocity [119]. They typically allow simultaneous measurement of 64-256 channels, with a sampling rate of up to $50 \mathrm{kHz}$. The data acquisition module also accommodates up to four extra channels to allow for the simultaneous measurement of other parameters such as temperature, $\mathrm{pH}$ or direct patch-clamp recording. The MEAs have been used to show that human ESC- and iPSCderived cardiomyocytes have physiological responses to drugs, thus showing their potential utility as a drug screening platform [36,119]. The main advantage of the MEA technology is the ability to noninvasively monitor the electrical activity of cells in culture over a long period [121]. The main disadvantages are the relatively small number of recording sites, small area of measurement and no direct information about the shape of the propagated action potentials.

\section{Optical mapping of action potential propagation using voltage- \& calcium-sensitive fluorescent dyes}

Fluorescent optical mapping has been well established as a noninvasive method for imaging electrical activity in whole hearts [122], cell monolayers [123] and, more recently, engineered tissue constructs [89,92,124]. For recordings of action potential shape and propagation, voltage-sensitive dyes such as di-4-ANEPPS, di-8-ANEPPS or RH237 [122] 
are often used in conjunction with high-numerical-aperture lenses and 'fast' cameras (charge-coupled device and complementary metal oxide semiconductor) or photodiode arrays $[122,123]$. The main advantage of this methodology is the ability to simultaneously monitor action potential shape at thousands of sites and to flexibly change the spatial resolution and field of view by simply switching the recording optics. On the other hand, voltage-sensitive dyes have inherent drawbacks such as bleaching, free radical-based phototoxicity and low quantum yield [125]. Optical methods are also used to measure intracellular calcium concentration in cardiomyocytes (either simultaneously with changes in membrane potential or alone) by using calcium-sensitive dyes such as rhod-2 and fluo- 4 . Compared with voltage-sensitive dyes, $\mathrm{Ca}^{2+}$ indicators have lower toxicity and baseline fluorescence and a much higher quantum yield, and can be used as a surrogate reporter of cardiac electrical activity [123]. More recently, genetically encoded intracellular $\mathrm{Ca}^{2+}$ sensors (e.g., gCaMP molecules) have been used as noninvasive reporters of electrical activity in a variety of cell types, such as cardiac and skeletal myoblasts [126]. The main advantage of genetic indicators is the possibility to perform long-term monitoring of $\mathrm{Ca}^{2+}$ concentrations in selected cells (containing indicator) in vitro or in vivo. The main disadvantage is a relatively low signal-to-noise ratio and slow $\mathrm{Ca}^{2+}$ binding kinetics compared with existing dye indicators.

\section{Use of force transducers for direct measurements of generated contractile force}

Mechanical forces produced during cardiomyocyte contraction can be measured at different spatial scales, from single-cell to whole-tissue constructs. To measure single-cell forces, isolated cardio myocytes can be glued on one end to an inflexible steel needle and on the other to a piezo-electric motor used to stretch the cardiomyocyte. The resulting contractile force is isometrically measured by a sensitive force transducer connected to the needle [127]. Contractile forces generated by spontaneously beating clusters of mouse ESC-, iPSCor human ESC-derived cardio myocytes have been measured by seeding these cells onto neonatal mouse ventricular slices avitalized by glucose and oxygen deprivation and connected to a force transducer [128-130]. The generated contractile force per cardiomyocyte cluster was found to be in the order of $1-1.5 \mu N$. Similarly, passive viscoelastic properties and contractile force generation of whole-tissue constructs made of primary or stem cell-derived cardiomyocytes have been assessed by a number of groups using adaptations of standard tissue-organ bath measurements $[59,89,100]$. Compared with single-cell measurements, the main disadvantage of tissue-level tests is a difficulty to derive contractile stress per cardiomyocyte, a measure of cellular function and maturity. The main advantage (besides larger signals and more durable preparation) is the ability to evaluate the potential for the therapeutic contribution of the tissue patch when implanted into the host myocardium. In addition to direct isometric force measurement tests, contractile force generation in cardiomyocytes and engineered cardiac tissues can be indirectly assessed by imaging the displacement of the polydimethylsiloxane films or posts to which the contractile cells or tissues are attached [131,132]. Careful calibration procedures and elastic bending theory are used to convert the measured displacement into a corresponding force value.

\section{Important considerations during measurements of tissue-level electrical function}

While synchronous macroscopic contractions are often used to indicate functional coupling in engineered cardiac tissues [91,133], coupling strengths as low as $0.5 \mathrm{nS}$ have been shown to be sufficient to entrain adjacent cardiomyocytes [134]. These levels of coupling are two to three orders of magnitude lower than those measured in neonatal and adult cardiomyocyte pairs $[135,136]$. On the other hand, velocity of action potential propagation (conduction velocity) represents a compound measure of the strength of gap junctional coupling, availability of sodium current for propagation (which depends both on sodium conductance and the cell's resting potential) and cell size, all of which change in defined manners during 
cardiac development. Thus, while often not measured in cardiac tissue-engineering studies $[78,91,100]$, conduction velocity, rather than synchronous contractions, should be assessed as a standard quantitative measure of tissue-level electrical function. Similarly, the maximum rate at which engineered cardiac tissues can be steadily stimulated by a point electrode depends on the expression and kinetics of repolarization and depolarization currents (and gap junctional coupling), and is yet another quantitative measure of cardiac electrical function. On the other hand, measurements of the minimum electrical field strength required to induce tissue stimulation ('excitation threshold'), although widely used to characterize the electrical function of tissues [133], needs to be carefully interpreted, as it depends not only on the cell excitability, but also on the cell orientation relative to electrodes, electrode and bath geometry and the presence and distribution of tissue heterogeneities (e.g., holes), which can facilitate cell excitation by acting as 'secondary excitation sources' [122]. In this case, undesirable, structurally heterogeneous tissue constructs with relatively low excitation thresholds could be incorrectly qualified as being highly functional.

\section{Important considerations during measurements of tissue-level mechanical function}

The tissue displacement during contraction ('contraction amplitude') can be conveniently measured using different video edge-detection techniques and is often assumed to directly correlate with the amplitude of contractile force produced by an engineered cardiac tissue construct $[96,133]$. However, the amplitude of the tissue contraction is highly dependent on the stiffness of the tissue construct (which is governed by scaffold type and degradation rate, extracellular matrix deposition by cells and specific culture conditions), local cell orientations and specifics of tissue geometry. As these factors may change with culture time within the same tissue construct and/or differ in different experimental groups, measurements of contraction amplitude are, at best, qualitative and potentially erroneous. The true quantitative measurements of contractile force should thus involve the use of standard force transducers and linear actuators $[78,89,100]$. Furthermore, during contractile force measurements, engineered cardiac tissues are often stimulated by strong field shocks $[78,89,100]$, which only probe the maximum contractile force of all simultaneously excited cardio myocytes, without taking into account the level of their coupling. By contrast, physiologically and therapeutically relevant measurements, where contractile force is generated secondarily to action potential propagation, can be performed by locally stimulating tissue constructs at one edge using near-threshold point pacing.

\section{Markers of cardiac structural \& functional differentiation in vivo}

One of the most important and as-yet unattained goals in the cardiac tissue-engineering field is the optimization of culture conditions to yield structural and functional differentiation of stem cell-derived cardiomyocytes with the time course that at least matches (and potentially surpasses) normal heart development. From studies of rodent development, several cardiac ultrastructural features (summarized in Table 4) can be used as guidelines in estimating the maturity of pluripotent stem cell-derived cardiomyocytes in vitro. Specifically, during development, early embryonic cardiomyocytes are rounded in shape [137] and primarily express connexin- 45 and connexin-40 gap junctions [138,139], as well as mechanical adherens junctions and desmosomes in a uniform circumferential pattern. As development progresses, connexin- 45 and connexin- 40 gap junctions are progressively downregulated and connexin-43 gap junctions are upregulated [138-140]. Simultaneously, the unorganized myofibrils in early cardiomyocytes become organized to form distinct I, A and Z bands in the later embryonic stages [141]. At prenatal stages, the pattern of gap junction expression changes from uniform to punctate. Cells start to attain well-defined rod shapes, and by 3-4 weeks postbirth, mechanical adherens junctions and desmosomes move to the longitudinal ends of the cardiomyocytes to form mature (staircase-shaped) intercalated discs [142]. By 
6-8 weeks postbirth, gap junctions also migrate to intercalated discs to colocalize with mechanical junctions. T-tubules appear as minor sarcolemmal invaginations in the late embryonic stage and gradually grow deep into the cytoplasm [41,137], achieving mature appearance 2-3 weeks after birth. The occurrence of T-tubules is associated with the formation of couplons and the appearance of calcium sparks [143]. As the T-tubules become fully mature, the L-type $\mathrm{Ca}^{2+}$ channels in T-tubules colocalize with Ryanodine receptors for more efficient excitation-contraction coupling.

The described structural maturation is paralleled by the functional changes in action potential shape, conduction, $\mathrm{Ca}^{2+}$ handling and generation of contractile force. Specifically, the depolarized resting potentials and fast spontaneous activity present in all cardiomyocytes during early embryonic stage are gradually replaced by a quiescent cell phenotype in atrial and ventricular myocytes. This phenotype is characterized by a more hyperpolarized resting membrane potential, shorter- and faster-rising cardiac action potentials and the ability of cardiomycoytes to propagate action potentials more rapidly and at higher excitation rates (Table 4). These changes are caused by the gradual alterations in the expression and kinetics of membrane ion channels and pumps [144]. Simultaneously with action potential changes, intracellular $\mathrm{Ca}^{2+}$ transients increase in amplitude and attain faster kinetics. Sarcolemmal $\mathrm{Ca}^{2+}$ inflow through L-type $\mathrm{Ca}^{2+}$ channels and $\mathrm{Na}^{+}-\mathrm{Ca}^{2+}$ exchanger, as the main source of the $\mathrm{Ca}^{2+}$ transients in embryonic cardio myocytes, becomes dominated by the release of $\mathrm{Ca}^{2+}$ from sarcoplasmic reticulum in postnatal and adult myocytes [145]. These cellular changes are paralleled at the organ level by an increase in the generated contractile stress (Table 4) and passive stiffness [146].

In general, while the structural and functional changes during cardiac development in humans are believed to correspond to those of rodents, the duration of human embryonic development is significantly longer ( 9 months vs 3 weeks). In fact, certain structural and functional properties in human cardiomyocytes become fully mature only after several months to years. For example, the adult-like membrane distribution of connexin-43 gap junctions is only achieved in human cardiomyocytes at the age of 6 years [147]. Therefore, it is not surprising that even after 60-90 days of culture, human ESC- and iPSC-derived cardiomyocytes are electrically and mechanical immature, as evident from their spontaneous automaticity (rate of $0.5-1 \mathrm{~Hz}$ [148]), relatively depolarized maximum diastolic potential ( -50 to $-64.3 \mathrm{vs}-87.84 \mathrm{mV}$ in adult human tissues [149]), relatively slow maximum upstroke velocity (5-40.5 vs $250 \mathrm{~V} / \mathrm{s}$ in adult human tissues [149]), absence of T-tubules, dependence of $\mathrm{Ca}^{2+}$ transients on sarcolemmal calcium inflow rather than sarcoplasmic reticulum release, lack of post-rest potentiation, no phospholamban or calsequestrin expression and negative force-frequency relationship [150,151]. While some ESC and iPSC studies show derivation of more mature (but still embryonic-like) human cardio myocytes [82,148,152], the critical question becomes how the process of in vitro human cardio genesis can be optimized to accelerate cardiomyocyte maturation and, in a relatively short time, obtain a cardiac functional phenotype that would yield safe and efficient cell and tissueengineering therapies.

\section{Conclusion \& future perspective}

Epicardial implantation of engineered cardiac tissue patch has been proposed as a potential therapy for myocardial infarction [3,153]. In several animal studies, this approach has been shown to provide additional benefits to cardiac function compared with cell injection $[15,16]$. Furthermore, the first clinical studies with adult stem cell-derived tissue patches suggest no apparent safety concerns for human use [22]. Nevertheless, much work remains to be done to demonstrate the safety and efficacy of tissue-engineering therapies (especially those using pluripotent stem cell-derived cardiomyocytes), both in preclinical models and in 
the context of human heart disease. In particular, in light of the arrhythmias reported in clinical trials with skeletal myoblasts [5], it will be crucial to show that implanted engineered cardiac tissue patches are not proarrhythmic (i.e., that it is able to electrically integrate with host myocardium without creating a local heterogeneity in action potential conduction or repolarization at physiologically relevant heart rates). In addition, a good match in mechanical and contractile properties between the implanted patch and surrounding tissue will be important to avoid the formation of nonphysiological strains and contraction patterns, which may not only compromise cardio myocyte survival, but may also induce or perpetuate arrhythmias through the process of mechanoelectric feedback $[154,155]$.

The assembly of stem cell-derived cardiomyocytes into functional engineered tissue is clearly not a trivial task, and the numerous attempts to date have had only limited success in generating relatively large, thick, aligned and highly functional cardiac tissues capable of integrating with the host's muscle and vascular system. Instead, most stem cell-derived engineered cardiac tissues show a lack of structural organization and only limited functionality relative to native myocardium and engineered tissues composed of primary neonatal cardiac cells $[68,78]$. One key strategy to enhance the functionality of engineered tissues is to develop methods to obtain relatively pure cardiogenic cell populations, either by genetic selection or identification of cardiac-specific membrane markers. Although genetic selection methods have become a common strategy with mouse ESCs $[60,89,97]$, it is much more difficult to generate stable genetically engineered human ESC cell lines for this purpose, primarily due to difficulties in passaging them as single cells. As stable integration of foreign genes would not be desirable in clinical applications, transient gene manipulation strategies [156] or excision of stably integrated genes (i.e., using Cre-Lox strategies [157]) should be considered for this purpose. Simultaneously, the use of feedback-control strategies and small-molecule cocktails may allow single-cell passaging and clonal expansion of human ESC and iPSC lines [158].

In addition, for advanced functional maturation, pure cardiogenic cells in tissue constructs will likely have to be supported by different noncardiomyocytes or their secreted factors. Recent studies have shown that cardiac fibroblasts mediate the formation of functional cardiac syncytium [89,97], while endothelial cells enhance the vascular integration of engineered tissues with host myocardium $[78,96]$. On the other hand, incorporating seemingly suitable cells from various parts of the body (e.g., human umbilical vein endothelial cells or MEFs $[78,96]$ ) into engineered cardiac tissues requires caution. Studies conducted on fibroblasts and endothelial cells from different parts of the body have shown an unexpected amount of transcriptional diversity $[159,160]$, indicating that even though a cell may fully perform its role in one tissue, this may not be the case in another.

Furthermore, even when from the same tissue, fibroblasts from different developmental stages have been shown to exert distinct effects on maturing cardiomyocytes [70]. We therefore suggest the use of a fully biomimetic approach where noncardiomyocytes utilized for cardiac tissue engineering should be both age-matched to cardiomyocytes and derived solely from the heart tissues. The use of multipotent cardiovascular progenitors $[66,67,85,89]$ could, to some extent, ensure the cardiac origin of supporting vascular cells. On the other hand, derivation of early cardiac fibroblasts remains difficult because their developmental origin and differentiation markers are still not well-defined.

In summary, we hope that future studies will increasingly utilize rigorous functional tests to guide the rational design of engineered cardiac tissues and systematically evaluate their potential to support the electrical and mechanical function of the heart. When standardized among different laboratories, the quantitative functional tests, along with the reproducible and efficient methods for cardiac cell differentiation and tissue fabrication, are expected to 
further unify efforts in the cardiac tissue-engineering field and lead the development of the next generation of cell-based cardiac therapies.

\section{Acknowledgments}

This work was supported by NIH-NHLBI grants HL095069 and HL104326 to N Bursac. B Liau is supported by a grant from the Agency for Science, Technology and Research, Singapore.

No writing assistance was utilized in the production of this manuscript.

\section{References}

Papers of special note have been highlighted as:

of interest

of considerable interest

1. Roger VL, Go AS, Lloyd-Jones DM, et al. Heart disease and stroke statistics - 2011 update: a report from the American Heart Association. Circulation. 2011; 123(4):E18-E209. [PubMed: 21160056]

2. Dowell JD, Rubart M, Pasumarthi KB, Soonpaa MH, Field LJ. Myocyte and myogenic stem cell transplantation in the heart. Cardiovasc. Res. 2003; 58(2):336-350. [PubMed: 12757868]

3. Murry CE, Field LJ, Menasche P. Cell-based cardiac repair: reflections at the 10-year point. Circulation. 2005; 112(20):3174-3183. [PubMed: 16286608]

4. Welt FG, Losordo DW. Cell therapy for acute myocardial infarction: curb your enthusiasm? Circulation. 2006; 113(10):1272-1274. [PubMed: 16534025]

5. Menasche P, Alfieri O, Janssens S, et al. The Myoblast Autologous Grafting in Ischemic Cardiomyopathy (MAGIC) trial: first randomized placebo-controlled study of myoblast transplantation. Circulation. 2008; 117(9):1189-1200. [PubMed: 18285565]

6. Davis ME, Hsieh PC, Takahashi T, et al. Local myocardial insulin-like growth factor 1 (IGF-1) delivery with biotinylated peptide nanofibers improves cell therapy for myocardial infarction. Proc. Natl Acad. Sci. USA. 2006; 103(21):8155-8160. [PubMed: 16698918]

7. Laflamme MA, Chen KY, Naumova AV, et al. Cardiomyocytes derived from human embryonic stem cells in pro-survival factors enhance function of infarcted rat hearts. Nat. Biotechnol. 2007; 25(9):1015-1024. [PubMed: 17721512]

8. Yang Y, Min JY, Rana JS, et al. VEGF enhances functional improvement of postinfarcted hearts by transplantation of ESC-differentiated cells. J. Appl. Physiol. 2002; 93(3):1140-1151. [PubMed: 12183512]

9. Zhang M, Methot D, Poppa V, Fujio Y, Walsh K, Murry CE. Cardiomyocyte grafting for cardiac repair: graft cell death and anti-death strategies. J. Mol. Cell. Cardiol. 2001; 33(5):907-921. [PubMed: 11343414]

10. Bursac N. Cardiac tissue engineering using stem cells. IEEE Eng. Med. Biol. Mag. 2009; 28(2):80, 82, 84-86, 88-89. [PubMed: 19353830]

11. Eschenhagen T, Zimmermann WH. Engineering myocardial tissue. Circ. Res. 2005; 97(12):12201231. [PubMed: 16339494]

12. Sekine H, Shimizu T, Dobashi I, et al. Cardiac cell sheet transplantation improves damaged heart function via superior cell survival in comparison with dissociated cell injection. Tissue Eng. Part A. 2011; 17(23-24):2973-2980. [PubMed: 21875331]

13. Langer R, Vacanti JP. Tissue engineering. Science. 1993; 260(5110):920-926. [PubMed: 8493529]

14. Menasche P, Hagege AA, Scorsin M, et al. Myoblast transplantation for heart failure. Lancet. 2001; 357(9252):279-280. [PubMed: 11214133]

15. Hata H, Matsumiya G, Miyagawa S, et al. Grafted skeletal myoblast sheets attenuate myocardial remodeling in pacing-induced canine heart failure model. J. Thorac. Cardiovasc. Surg. 2006; 132(4):918-924. [PubMed: 17000305] 
16. Siepe M, Giraud MN, Pavlovic M, et al. Myoblast-seeded biodegradable scaffolds to prevent postmyocardial infarction evolution toward heart failure. J. Thorac. Cardiovasc. Surg. 2006; 132(1): 124-131. [PubMed: 16798312]

17. Leobon B, Garcin I, Menasche P, Vilquin JT, Audinat E, Charpak S. Myoblasts transplanted into rat infarcted myocardium are functionally isolated from their host. Proc. Natl Acad. Sci. USA. 2003; 100(13):7808-7811. [PubMed: 12805561] First paper clearly showing that transplanted skeletal myoblasts are isolated from surrounding myocardium.

18. Sawa Y, Miyagawa S, Sakaguchi T, et al. Tissue engineered myoblast sheets improved cardiac function sufficiently to discontinue LVAS in a patient with DCM: report of a case. Surg. Today. 2012; 42(2):181-184. [PubMed: 22200756]

19. Sawa Y. Myocardial regeneration for heart failure. Nihon Rinsho. 2010; 68(4):719-725. [PubMed: 20387567]

20. Lovell MJ, Mathur A. Cardiac stem cell therapy: progress from the bench to bedside. Heart. 2010; 96(19):1531-1537. [PubMed: 20668107]

21. Malliaras K, Marban E. Cardiac cell therapy: where we've been, where we are, and where we should be headed. Br. Med. Bull. 2011; 98:161-185. [PubMed: 21652595]

22 Chachques JC, Trainini JC, Lago N, Cortes-Morichetti M, Schussler O, Carpentier A. Myocardial Assistance by Grafting a New Bioartificial Upgraded Myocardium (MAGNUM trial): clinical feasibility study. Ann. Thorac. Surg. 2008; 85(3):901-908. [PubMed: 18291168] First clinical trial involving transplantation of engineered tissue for treatment of myocardial infarction.

23ם. Wollert KC, Meyer GP, Lotz J, et al. Intracoronary autologous bone-marrow cell transfer after myocardial infarction: the BOOST randomised controlled clinical trial. Lancet. 2004; 364(9429): 141-148. [PubMed: 15246726] First randomized trial with bone marrow-derived stromal cells.

24. Beltrami AP, Barlucchi L, Torella D, et al. Adult cardiac stem cells are multipotent and support myocardial regeneration. Cell. 2003; 114(6):763-776. [PubMed: 14505575]

25. Strem BM, Zhu M, Alfonso Z, et al. Expression of cardiomyocytic markers on adipose tissuederived cells in a murine model of acute myocardial injury. Cytotherapy. 2005; 7(3):282-291. [PubMed: 16081355]

26. Rose RA, Jiang H, Wang X, et al. Bone marrow-derived mesenchymal stromal cells express cardiac-specific markers, retain the stromal phenotype, and do not become functional cardiomyocytes in vitro. Stem Cells. 2008; 26(11):2884-2892. [PubMed: 18687994]

27. Guan K, Wagner S, Unsold B, et al. Generation of functional cardiomyocytes from adult mouse spermatogonial stem cells. Circ. Res. 2007; 100(11):1615-1625. [PubMed: 17478732]

28. Revazova ES, Turovets NA, Kochetkova OD, et al. Patient-specific stem cell lines derived from human parthenogenetic blastocysts. Cloning Stem Cells. 2007; 9(3):432-449. [PubMed: 17594198]

29. Cibelli JB, Cunniff K, Vrana KE. Embryonic stem cells from parthenotes. Methods Enzymol. 2006; 418:117-135. [PubMed: 17141033]

30. Wakayama T, Tabar V, Rodriguez I, Perry AC, Studer L, Mombaerts P. Differentiation of embryonic stem cell lines generated from adult somatic cells by nuclear transfer. Science. 2001; 292(5517):740-743. [PubMed: 11326103]

31․ Takahashi K, Tanabe K, Ohnuki M, et al. Induction of pluripotent stem cells from adult human fibroblasts by defined factors. Cell. 2007; 131(5):861-872. [PubMed: 18035408] Along with [51], one of two landmark papers showing the induction of pluripotency by defined factors in human cells.

32. Takahashi K, Yamanaka S. Induction of pluripotent stem cells from mouse embryonic and adult fibroblast cultures by defined factors. Cell. 2006; 126(4):663-676. [PubMed: 16904174] First paper to show the induction of pluripotency by defined factors in mouse cells.

33. Kehat I, Gepstein A, Spira A, Itskovitz-Eldor J, Gepstein L. High-resolution electrophysiological assessment of human embryonic stem cell-derived cardiomyocytes: a novel in vitro model for the study of conduction. Circ. Res. 2002; 91(8):659-661. [PubMed: 12386141] 
34. Wobus AM, Wallukat G, Hescheler J. Pluripotent mouse embryonic stem cells are able to differentiate into cardiomyocytes expressing chronotropic responses to adrenergic and cholinergic agents and $\mathrm{Ca}^{2+}$ channel blockers. Differentiation. 1991; 48(3):173-182. [PubMed: 1725163]

35. Zhang J, Wilson GF, Soerens AG, et al. Functional cardiomyocytes derived from human induced pluripotent stem cells. Circ. Res. 2009; 104(4):E30-E41. [PubMed: 19213953]

36. Itzhaki I, Maizels L, Huber I, et al. Modelling the long QT syndrome with induced pluripotent stem cells. Nature. 2011; 471(7337):225-229. [PubMed: 21240260]

37. Koninckx R, Daniëls A, Windmolders S, et al. Mesenchymal stem cells or cardiac progenitors for cardiac repair? A comparative study. Cell. Mol. Life Sci. 2011; 68(12):2141-2156. [PubMed: 20972814]

38. Rangappa S, Fen C, Lee EH, Bongso A, Sim EK. Transformation of adult mesenchymal stem cells isolated from the fatty tissue into cardiomyocytes. Ann. Thorac. Surg. 2003; 75(3):775-779. [PubMed: 12645692]

39. He JQ, Ma Y, Lee Y, Thomson JA, Kamp TJ. Human embryonic stem cells develop into multiple types of cardiac myocytes: action potential characterization. Circ. Res. 2003; 93(1):32-39. [PubMed: 12791707]

40. Yang L, Soonpaa MH, Adler ED, et al. Human cardiovascular progenitor cells develop from a $\mathrm{KDR}^{+}$embryonic-stem-cell-derived population. Nature. 2008; 453(7194):524-528. [PubMed: 18432194]

41. Ziman AP, Gomez-Viquez NL, Bloch RJ, Lederer WJ. Excitation-contraction coupling changes during postnatal cardiac development. J. Mol. Cell Cardiol. 2010; 48(2):379-386. [PubMed: 19818794]

42. Kehat I, Khimovich L, Caspi O, et al. Electromechanical integration of cardiomyocytes derived from human embryonic stem cells. Nat. Biotechnol. 2004; 22(10):1282-1289. [PubMed: 15448703]

43. Matsuda T, Nakamura T, Nakao K, et al. STAT3 activation is sufficient to maintain an undifferentiated state of mouse embryonic stem cells. EMBO J. 1999; 18(15):4261-4269. [PubMed: 10428964]

44. Ying QL, Nichols J, Chambers I, Smith A. BMP induction of Id proteins suppresses differentiation and sustains embryonic stem cell self-renewal in collaboration with STAT3. Cell. 2003; 115(3): 281-292. [PubMed: 14636556]

45. Ginis I, Luo Y, Miura T, et al. Differences between human and mouse embryonic stem cells. Dev. Biol. 2004; 269(2):360-380. [PubMed: 15110706]

46. Kawase E, Suemori H, Takahashi N, Okazaki K, Hashimoto K, Nakatsuji N. Strain difference in establishment of mouse embryonic stem (ES) cell lines. Int. J. Dev. Biol. 1994; 38(2):385-390. [PubMed: 7981049]

47. Bendall SC, Stewart MH, Menendez P, et al. IGF and FGF cooperatively establish the regulatory stem cell niche of pluripotent human cells in vitro. Nature. 2007; 448(7157):1015-1021. [PubMed: 17625568]

48. Hayashi Y, Furue MK, Tanaka S, et al. BMP4 induction of trophoblast from mouse embryonic stem cells in defined culture conditions on laminin. In Vitro Cell. Dev. Biol. Anim. 2010; 46(5): 416-430. [PubMed: 20033790]

49. Okita K, Yamanaka S. Induced pluripotent stem cells: opportunities and challenges. Philos. Trans. R. Soc. Lond. B Biol. Sci. 2011; 366(1575):2198-2207. [PubMed: 21727125]

50. Yoshida Y, Yamanaka S. iPS cells: a source of cardiac regeneration. J. Mol. Cell Cardiol. 2011; 50(2):327-332. [PubMed: 21040726]

51‥ Yu J, Vodyanik MA, Smuga-Otto K, et al. Induced pluripotent stem cell lines derived from human somatic cells. Science. 2007; 318(5858):1917-1920. [PubMed: 18029452] Along with [31], one of two landmark papers showing the induction of pluripotency by defined factors in human cells.

52. Nakagawa M, Koyanagi M, Tanabe K, et al. Generation of induced pluripotent stem cells without Myc from mouse and human fibroblasts. Nat. Biotechnol. 2008; 26(1):101-106. [PubMed: 18059259] 
53. Huangfu D, Osafune K, Maehr R, et al. Induction of pluripotent stem cells from primary human fibroblasts with only Oct4 and Sox2. Nat. Biotechnol. 2008; 26(11):1269-1275. [PubMed: 18849973]

54. Yu J, Hu K, Smuga-Otto K, et al. Human induced pluripotent stem cells free of vector and transgene sequences. Science. 2009; 324(5928):797-801. [PubMed: 19325077]

55. Yusa K, Rad R, Takeda J, Bradley A. Generation of transgene-free induced pluripotent mouse stem cells by the piggyBac transposon. Nat. Methods. 2009; 6(5):363-369. [PubMed: 19337237]

56. Woltjen K, Michael IP, Mohseni P, et al. piggyBac transposition reprograms fibroblasts to induced pluripotent stem cells. Nature. 2009; 458(7239):766-770. [PubMed: 19252478]

57. Warren L, Manos PD, Ahfeldt T, et al. Highly efficient reprogramming to pluripotency and directed differentiation of human cells with synthetic modified mRNA. Cell Stem Cell. 2010; 7(5): 618-630. [PubMed: 20888316]

58. Stadtfeld M, Nagaya M, Utikal J, Weir G, Hochedlinger K. Induced pluripotent stem cells generated without viral integration. Science. 2008; 322(5903):945-949. [PubMed: 18818365]

59. Zhou H, Wu S, Joo JY, et al. Generation of induced pluripotent stem cells using recombinant proteins. Cell Stem Cell. 2009; 4(5):381-384. [PubMed: 19398399]

60. Shimko VF, Claycomb WC. Effect of mechanical loading on three-dimensional cultures of embryonic stem cell-derived cardiomyocytes. Tissue Eng. Part A. 2008; 14(1):49-58. [PubMed: 18333804]

61. Nakano T, Kodama H, Honjo T. Generation of lymphohematopoietic cells from embryonic stem cells in culture. Science. 1994; 265(5175):1098-1101. [PubMed: 8066449]

62. Flaim CJ, Chien S, Bhatia SN. An extracellular matrix microarray for probing cellular differentiation. Nat. Methods. 2005; 2(2):119-125. [PubMed: 15782209]

63. Kattman SJ, Witty AD, Gagliardi M, et al. Stage-specific optimization of activin/nodal and BMP signaling promotes cardiac differentiation of mouse and human pluripotent stem cell lines. Cell Stem Cell. 2011; 8(2):228-240. [PubMed: 21295278]

64. Murry CE, Keller G. Differentiation of embryonic stem cells to clinically relevant populations: lessons from embryonic development. Cell. 2008; 132(4):661-680. [PubMed: 18295582]

65. Boheler KR, Czyz J, Tweedie D, Yang HT, Anisimov SV, Wobus AM. Differentiation of pluripotent embryonic stem cells into cardiomyocytes. Circ. Res. 2002; 91(3):189-201. [PubMed: 12169644]

66. Christoforou N, Miller RA, Hill CM, Jie CC, Mccallion AS, Gearhart JD. Mouse ES cell-derived cardiac precursor cells are multipotent and facilitate identification of novel cardiac genes. J. Clin. Invest. 2008; 118(3):894-903. [PubMed: 18246200]

67. Moretti A, Caron L, Nakano A, et al. Multipotent embryonic Isl1 ${ }^{+}$progenitor cells lead to cardiac, smooth muscle, and endothelial cell diversification. Cell. 2006; 127(6):1151-1165. [PubMed: 17123592]

68. Guo XM, Zhao YS, Chang HX, et al. Creation of engineered cardiac tissue in vitro from mouse embryonic stem cells. Circulation. 2006; 113(18):2229-2237. [PubMed: 16651472] First paper showing tissue-engineered cardiac constructs derived from pluripotent stem cells.

69. Muller M, Fleischmann BK, Selbert S, et al. Selection of ventricular-like cardiomyocytes from ES cells in vitro. FASEB J. 2000; 14(15):2540-2548. [PubMed: 11099473]

70. Ieda M, Tsuchihashi T, Ivey KN, et al. Cardiac fibroblasts regulate myocardial proliferation through beta1 integrin signaling. Dev. Cell. 2009; 16(2):233-244. [PubMed: 19217425]

71. Klug MG, Soonpaa MH, Koh GY, Field LJ. Genetically selected cardiomyocytes from differentiating embronic stem cells form stable intracardiac grafts. J. Clin. Invest. 1996; 98(1): 216-224. [PubMed: 8690796]

72. Fijnvandraat AC, Van Ginneken AC, Schumacher CA, et al. Cardiomyocytes purified from differentiated embryonic stem cells exhibit characteristics of early chamber myocardium. J. Mol. Cell Cardiol. 2003; 35(12):1461-1472. [PubMed: 14654372]

73. Cameron CM, Hu W-S, Kaufman DS. Improved development of human embryonic stem cellderived embryoid bodies by stirred vessel cultivation. Biotechnol. Bioeng. 2006; 94(5):938-948. [PubMed: 16547998] 
74. Hirata H, Kawamata S, Murakami Y, et al. Coexpression of platelet-derived growth factor receptor alpha and fetal liver kinase 1 enhances cardiogenic potential in embryonic stem cell differentiation in vitro. J. Biosci. Bioeng. 2007; 103(5):412-419. [PubMed: 17609155]

75. Nelson TJ, Faustino RS, Chiriac A, Crespo-Diaz R, Behfar A, Terzic A. CXCR4/FLK-1 ${ }^{+}$ biomarkers select a cardiopoietic lineage from embryonic stem cells. Stem Cells. 2008; 26(6): 1464-1473. [PubMed: 18369102]

76. Hattori F, Chen H, Yamashita H, et al. Nongenetic method for purifying stem cell-derived cardiomyocytes. Nat. Methods. 2010; 7(1):61-66. [PubMed: 19946277] First paper showing that pluripotent stem cell-derived cardiomyocytes can be purified with high efficiency using nongenetic methods involving mitochondrial dyes.

77. Mummery C, Ward D, Van Den Brink CE, et al. Cardiomyocyte differentiation of mouse and human embryonic stem cells. J. Anat. 2002; 200(Pt 3):233-242. [PubMed: 12033727]

78. Tulloch NL, Muskheli V, Razumova MV, et al. Growth of engineered human myocardium with mechanical loading and vascular coculture. Circ. Res. 2011; 109(1):47-59. [PubMed: 21597009] One of the first human embryonic stem cell-based cardiac tissue-engineering papers to focus on tissue function.

79. Dubois NC, Craft AM, Sharma P, et al. SIRPA is a specific cell-surface marker for isolating cardiomyocytes derived from human pluripotent stem cells. Nat. Biotechnol. 2011; 29(11):10111018. [PubMed: 22020386]

80. Elliott DA, Braam SR, Koutsis K, et al. Nkx2-5eGFP/w hESCs for isolation of human cardiac progenitors and cardiomyocytes. Nat. Methods. 2011; 8(12):1037-1040. [PubMed: 22020065]

81. Mummery C. Genetic selection of cardiomyocytes from human embryonic stem cells. Mol. Ther. 2007; 15(11):1908-1909. [PubMed: 17948047]

82. Huber I, Itzhaki I, Caspi O, et al. Identification and selection of cardiomyocytes during human embryonic stem cell differentiation. FASEB J. 2007; 21(10):2551-2563. [PubMed: 17435178] Along with [83], one of the first papers to demonstrate successful genetic selection of human embryonic stem cell-derived cardiomyocytes.

83 . Anderson D, Self T, Mellor IR, Goh G, Hill SJ, Denning C. Transgenic enrichment of cardiomyocytes from human embryonic stem cells. Mol. Ther. 2007; 15(11):2027-2036. [PubMed: 17895862] Along with [82], one of the first papers to demonstrate successful genetic selection of human embryonic stem cell-derived cardiomyocytes.

84. Kim C, Majdi M, Xia P, et al. Non-cardiomyocytes influence the electrophysiological maturation of human embryonic stem cell-derived cardiomyocytes during differentiation. Stem Cells Dev. 2010; 19(6):783-795. [PubMed: 20001453]

85. Bu L, Jiang X, Martin-Puig S, et al. Human Isl1 heart progenitors generate diverse multipotent cardiovascular cell lineages. Nature. 2009; 460(7251):113-117. [PubMed: 19571884]

86. Blin G, Nury D, Stefanovic S, et al. A purified population of multipotent cardiovascular progenitors derived from primate pluripotent stem cells engrafts in postmyocardial infarcted nonhuman primates. J. Clin. Invest. 2010; 120(4):1125-1139. [PubMed: 20335662]

87. Srivastava D, Olson EN. A genetic blueprint for cardiac development. Nature. 2000; 407(6801): 221-226. [PubMed: 11001064]

88. Zimmermann WH, Schneiderbanger K, Schubert P, et al. Tissue engineering of a differentiated cardiac muscle construct. Circ. Res. 2002; 90(2):223-230. [PubMed: 11834716] First paper to use mechanical conditioning of ring-shaped engineered cardiac tissues to enhance their function.

89. Liau B, Christoforou N, Leong KW, Bursac N. Pluripotent stem cell-derived cardiac tissue patch with advanced structure and function. Biomaterials. 2011; 32(35):9180-9187. [PubMed: 21906802] Along with [97], one of the first papers to demonstrate that cardiac fibroblasts are necessary to support the formation of a functional embryonic stem cell-derived engineered cardiac tissue.

90. Yildirim Y, Naito H, Didie M, et al. Development of a biological ventricular assist device: preliminary data from a small animal model. Circulation. 2007; 116(Suppl. 11):I16-I23. [PubMed: 17846298]

91 . Caspi O, Lesman A, Basevitch Y, et al. Tissue engineering of vascularized cardiac muscle from human embryonic stem cells. Circ. Res. 2007; 100(2):263-272. [PubMed: 17218605] One of the 
first human embryonic stem cell-based cardiac tissue-engineering papers, albeit lacking any functional measurements.

92 $\square$. Bursac N, Loo Y, Leong K, Tung L. Novel anisotropic engineered cardiac tissues: studies of electrical propagation. Biochem. Biophys. Res. Commun. 2007; 361(4):847-853. [PubMed: 17689494] First paper showing optical mapping of action potential propagation in engineered tissues.

93. Radisic M, Deen W, Langer R, Vunjak-Novakovic G. Mathematical model of oxygen distribution in engineered cardiac tissue with parallel channel array perfused with culture medium containing oxygen carriers. Am. J. Physiol. Heart Circ. Physiol. 2005; 288(3):H1278-H1289. [PubMed: 15539422]

94. Engelmayr GC Jr, Cheng M, Bettinger CJ, Borenstein JT, Langer R, Freed LE. Accordion-like honeycombs for tissue engineering of cardiac anisotropy. Nat. Mater. 2008; 7(12):1003-1010. [PubMed: 18978786]

95. Pham QP, Sharma U, Mikos AG. Electrospinning of polymeric nanofibers for tissue engineering applications: a review. Tissue Eng. 2006; 12(5):1197-1211. [PubMed: 16771634]

96ロ. Stevens KR, Kreutziger KL, Dupras SK, et al. Physiological function and transplantation of scaffold-free and vascularized human cardiac muscle tissue. Proc. Natl Acad. Sci. USA. 2009; 106(39):16568-16573. [PubMed: 19805339] First paper to demonstrate transplantation and engraftment of a prevascularized human embryonic stem cell-derived cardiac tissue patch in an animal model.

97. Matsuura K, Masuda S, Haraguchi Y, et al. Creation of mouse embryonic stem cell-derived cardiac cell sheets. Biomaterials. 2011; 32(30):7355-7362. [PubMed: 21807408] Along with [89], one of the first papers to demonstrate that cardiac fibroblasts are necessary to support the formation of a functional embryonic stem cell-derived engineered cardiac tissue.

98 Ott HC, Matthiesen TS, Goh SK, et al. Perfusion-decellularized matrix: using nature's platform to engineer a bioartificial heart. Nat. Med. 2008; 14(2):213-221. [PubMed: 18193059] First paper showing that decellularized extracellular matrix could theoretically be used to engineer a whole heart.

99 Morritt AN, Bortolotto SK, Dilley RJ, et al. Cardiac tissue engineering in an in vivo vascularized chamber. Circulation. 2007; 115(3):353-360. [PubMed: 17200440] First paper demonstrating a novel method of engineering vascularized cardiac tissue using an implanted in vivo chamber.

100匹. Zimmermann WH, Melnychenko I, Wasmeier G, et al. Engineered heart tissue grafts improve systolic and diastolic function in infarcted rat hearts. Nat. Med. 2006; 12(4):452-458. [PubMed: 16582915] First detailed proof-of-concept study showing that engineered cardiac tissues (made of primary cardiac cells) can functionally integrate with the host tissue and significantly improve the cardiac function post-myocardial infarction.

101 . Bian W, Liau B, Badie N, Bursac N. Mesoscopic hydrogel molding to control the 3D geometry of bioartificial muscle tissues. Nat. Protoc. 2009; 4(10):1522-1534. [PubMed: 19798085] One of the first published protocols to reproducibly generate alignment of cardiac cells within large 3D tissue constructs using a microfabrication-based method.

102. Makarenko I, Opitz CA, Leake MC, et al. Passive stiffness changes caused by upregulation of compliant titin isoforms in human dilated cardiomyopathy hearts. Circ. Res. 2004; 95(7):708716. [PubMed: 15345656]

103. Hasenfuss G, Reinecke H, Studer R, et al. Relation between myocardial function and expression of sarcoplasmic reticulum $\mathrm{Ca}^{2+}$-ATPase in failing and nonfailing human myocardium. Circ. Res. 1994; 75(3):434-442. [PubMed: 8062417]

104. Naito H, Melnychenko I, Didie M, et al. Optimizing engineered heart tissue for therapeutic applications as surrogate heart muscle. Circulation. 2006; 114(1 Suppl.):I72-I78. [PubMed: 16820649]

105. Radisic M, Park H, Shing H, et al. Functional assembly of engineered myocardium by electrical stimulation of cardiac myocytes cultured on scaffolds. Proc. Natl Acad. Sci. USA. 2004; 101(52): 18129-18134. [PubMed: 15604141]

106. Stevens KR, Pabon L, Muskheli V, Murry CE. Scaffold-free human cardiac tissue patch created from embryonic stem cells. Tissue Eng. Part A. 2009; 15(6):1211-1222. [PubMed: 19063661] 
107. Cai CL, Liang X, Shi Y, et al. Isl1 identifies a cardiac progenitor population that proliferates prior to differentiation and contributes a majority of cells to the heart. Dev. Cell. 2003; 5(6):877-889. [PubMed: 14667410]

108. Van Laake LW, Qian L, Cheng P, et al. Reporter-based isolation of induced pluripotent stem celland embryonic stem cell-derived cardiac progenitors reveals limited gene expression variance. Circ. Res. 2010; 107(3):340-347. [PubMed: 20558827]

109. Christoforou N, Oskouei BN, Esteso P, et al. Implantation of mouse embryonic stem cell-derived cardiac progenitor cells preserves function of infarcted murine hearts. PLoS One. 2010; 5(7):E11536. [PubMed: 20634944]

110. Hansen A, Eder A, Bonstrup M, et al. Development of a drug screening platform based on engineered heart tissue. Circ. Res. 2010; 107(1):35-44. [PubMed: 20448218]

111. Fink C, Ergun S, Kralisch D, Remmers U, Weil J, Eschenhagen T. Chronic stretch of engineered heart tissue induces hypertrophy and functional improvement. FASEB J. 2000; 14(5):669-679. [PubMed: 10744624]

112. Akhyari P, Fedak PW, Weisel RD, et al. Mechanical stretch regimen enhances the formation of bioengineered autologous cardiac muscle grafts. Circulation. 2002; 106(12 Suppl. 1):I137-I142. [PubMed: 12354723]

113. Sauer H, Rahimi G, Hescheler J, Wartenberg M. Effects of electrical fields on cardiomyocyte differentiation of embryonic stem cells. J. Cell Biochem. 1999; 75(4):710-723. [PubMed: 10572253]

114. Serena E, Figallo E, Tandon N, et al. Electrical stimulation of human embryonic stem cells: cardiac differentiation and the generation of reactive oxygen species. Exp. Cell Res. 2009; 315(20):3611-3619. [PubMed: 19720058]

115. Neher E, Sakmann B. Single-channel currents recorded from membrane of denervated frog muscle fibres. Nature. 1976; 260(5554):799-802. [PubMed: 1083489]

116. Hamill OP, Marty A, Neher E, Sakmann B, Sigworth FJ. Improved patch-clamp techniques for high-resolution current recording from cells and cell-free membrane patches. Pflugers Arch. 1981; 391(2):85-100. [PubMed: 6270629]

117. Del Corsso C, Srinivas M, Urban-Maldonado M, et al. Transfection of mammalian cells with connexins and measurement of voltage sensitivity of their gap junctions. Nat. Protoc. 2006; 1(4): 1799-1809. [PubMed: 17487162]

118. Brown, KT.; Flaming, DG., editors. Advanced Micropipette Techniques for Cell Physiology. John Wiley \& Sons; NJ, USA: 1986.

119. Reppel M, Pillekamp F, Brockmeier K, et al. The electrocardiogram of human embryonic stem cell-derived cardiomyocytes. J. Electrocardiol. 2005; 38(Suppl. 4):166-170. [PubMed: 16226094]

120. Ameen C, Strehl R, Bjorquist P, Lindahl A, Hyllner J, Sartipy P. Human embryonic stem cells: current technologies and emerging industrial applications. Crit. Rev. Oncol. Hematol. 2008; 65(1):54-80. [PubMed: 17689256]

121. Ponard JG, Kondratyev AA, Kucera JP. Mechanisms of intrinsic beating variability in cardiac cell cultures and model pacemaker networks. Biophys. J. 2007; 92(10):3734-3752. [PubMed: 17325022]

122. Efimov IR, Nikolski VP, Salama G. Optical imaging of the heart. Circ. Res. 2004; 95(1):21-33. [PubMed: 15242982]

123. Tung L, Zhang Y. Optical imaging of arrhythmias in tissue culture. J. Electrocardiol. 2006; 39(Suppl. 4):S2-S6. [PubMed: 17015066]

124. Radisic M, Fast VG, Sharifov OF, Iyer RK, Park H, Vunjak-Novakovic G. Optical mapping of impulse propagation in engineered cardiac tissue. Tissue Eng. Part A. 2009; 15(4):851-860. [PubMed: 18847360]

125. Rohr S, Salzberg BM. Multiple site optical recording of transmembrane voltage (MSORTV) in patterned growth heart cell cultures: assessing electrical behavior, with microsecond resolution, on a cellular and subcellular scale. Biophys. J. 1994; 67(3):1301-1315. [PubMed: 7811945]

126. Roell W, Lewalter T, Sasse P, et al. Engraftment of connexin 43-expressing cells prevents postinfarct arrhythmia. Nature. 2007; 450(7171):819-824. [PubMed: 18064002] 
127. Van Der Velden J, Klein LJ, Zaremba R, et al. Effects of calcium, inorganic phosphate, and pH on isometric force in single skinned cardiomyocytes from donor and failing human hearts. Circulation. 2001; 104(10):1140-1146. [PubMed: 11535570]

128. Pfannkuche K, Liang H, Hannes T, et al. Cardiac myocytes derived from murine reprogrammed fibroblasts: intact hormonal regulation, cardiac ion channel expression and development of contractility. Cell. Physiol. Biochem. 2009; 24(1-2):73-86. [PubMed: 19590195]

129. Pillekamp F, Reppel M, Dinkelacker V, et al. Establishment and characterization of a mouse embryonic heart slice preparation. Cell. Physiol. Biochem. 2005; 16(1-3):127-132. [PubMed: 16121041]

130. Pillekamp F, Reppel M, Rubenchyk O, et al. Force measurements of human embryonic stem cellderived cardiomyocytes in an in vitro transplantation model. Stem Cells. 2007; 25(1):174-180. [PubMed: 16973834]

131 . Domian IJ, Chiravuri M, Van Der Meer P, et al. Generation of functional ventricular heart muscle from mouse ventricular progenitor cells. Science. 2009; 326(5951):426-429. [PubMed: 19833966] One of the first papers showing a functional 2D syncytium of aligned cardiomyocytes derived from mouse cardiovascular progenitors.

132. Legant WR, Pathak A, Yang MT, Deshpande VS, McMeeking RM, Chen CS. Microfabricated tissue gauges to measure and manipulate forces from 3D microtissues. Proc. Natl Acad. Sci. USA. 2009; 106(25):10097-10102. [PubMed: 19541627]

133. Song H, Yoon C, Kattman SJ, et al. Interrogating functional integration between injected pluripotent stem cell-derived cells and surrogate cardiac tissue. Proc. Natl Acad. Sci. USA. 2010; 107(8):3329-3334. [PubMed: 19846783]

134. Verheijck EE, Wilders R, Joyner RW, et al. Pacemaker synchronization of electrically coupled rabbit sinoatrial node cells. J. Gen. Physiol. 1998; 111(1):95-112. [PubMed: 9417138]

135. Kameyama M. Electrical coupling between ventricular paired cells isolated from guinea-pig heart. J. Physiol. 1983; 336:345-357. [PubMed: 6875911]

136. Yao JA, Hussain W, Patel P, Peters NS, Boyden PA, Wit AL. Remodeling of gap junctional channel function in epicardial border zone of healing canine infarcts. Circ. Res. 2003; 92(4):437443. [PubMed: 12600896]

137. Baharvand H, Piryaei A, Rohani R, Taei A, Heidari MH, Hosseini A. Ultrastructural comparison of developing mouse embryonic stem cell- and in vivo-derived cardiomyocytes. Cell Biol. Int. 2006; 30:800-807. [PubMed: 16877013]

138. Hirschy A, Schatzmann F, Ehler E, Perriard JC. Establishment of cardiac cytoarchitecture in the developing mouse heart. Dev. Biol. 2006; 289(2):430-441. [PubMed: 16337936]

139. Alcoléa S, Théveniau-Ruissy M, Jarry-Guichard T, et al. Downregulation of connexin 45 gene products during mouse heart development. Circ. Res. 1999; 84:1365-1379. [PubMed: 10381888]

140. Van Kempen MJ, Vermeulen JL, Moorman AF, Gros D, Paul DL, Lamers WH. Developmental changes of connexin 40 and connexin43 mRNA distribution patterns in the rat heart. Cardiovasc. Res. 1996; 32:886-900. [PubMed: 8944820]

141. Chacko KJ. Observations on the ultrastructure of developing myocardium of rat embryos. J. Morphol. 1976; 150:681-709. [PubMed: 1003489]

142. Angst BD, Khan LU, Severs NJ, et al. Dissociated spatial patterning of gap junctions and cell adhesion junctions during postnatal differentiation of ventricular myocardium. Circ. Res. 1997; 80(1):88-94. [PubMed: 8978327]

143. Seki S, Nagashima M, Yamada Y, et al. Fetal and postnatal development of $\mathrm{Ca}^{2+}$ transients and $\mathrm{Ca}^{2+}$ sparks in rat cardiomyocytes. Cardiovasc. Res. 2003; 58:535-548. [PubMed: 12798426]

144. Wetzel GT, Klitzner TS. Developmental cardiac electrophysiology recent advances in cellular physiology. Cardiovasc. Res. 1996; 31(Spec. No.):E52-E60. [PubMed: 8681346]

145. Escobar AL, Ribeiro-Costa R, Villalba-Galea C, Zoghbi ME, Perez CG, Mejia-Alvarez R. Developmental changes of intracellular $\mathrm{Ca}^{2+}$ transients in beating rat hearts. Am. J. Physiol. Heart Circ. Physiol. 2004; 286(3):H971-H978. [PubMed: 14644760]

146. Lahmers S, Wu Y, Call DR, Labeit S, Granzier H. Developmental control of titin isoform expression and passive stiffness in fetal and neonatal myocardium. Circ. Res. 2004; 94(4):505513. [PubMed: 14707027] 
147. Peters NS, Severs NJ, Rothery SM, Lincoln C, Yacoub MH, Green CR. Spatiotemporal relation between gap junctions and fascia adherens junctions during postnatal development of human ventricular myocardium. Circulation. 1994; 90(2):713-725. [PubMed: 8044940]

148. Satin J, Itzhaki I, Rapoport S, et al. Calcium handling in human embryonic stem cell-derived cardiomyocytes. Stem Cells. 2008; 26(8):1961-1972. [PubMed: 18483424]

149. O'Hara T, Virag L, Varro A, Rudy Y. Simulation of the undiseased human cardiac ventricular action potential: model formulation and experimental validation. PLoS Comput. Biol. 2011; 7(5):E1002061. [PubMed: 21637795]

150. Dolnikov K, Shilkrut M, Zeevi-Levin N, et al. Functional properties of human embryonic stem cell-derived cardiomyocytes: intracellular $\mathrm{Ca}^{2+}$ handling and the role of sarcoplasmic reticulum in the contraction. Stem Cells. 2006; 24(2):236-245. [PubMed: 16322641]

151. Liu J, Fu JD, Siu CW, Li RA. Functional sarcoplasmic reticulum for calcium handling of human embryonic stem cell-derived cardiomyocytes: insights for driven maturation. Stem Cells. 2007; 25(12):3038-3044. [PubMed: 17872499]

152. Sartiani L, Bettiol E, Stillitano F, Mugelli A, Cerbai E, Jaconi ME. Developmental changes in cardiomyocytes differentiated from human embryonic stem cells: a molecular and electrophysiological approach. Stem Cells. 2007; 25(5):1136-1144. [PubMed: 17255522]

153. Laflamme MA, Murry CE. Regenerating the heart. Nat. Biotechnol. 2005; 23(7):845-856. [PubMed: 16003373]

154. Miura M, Nishio T, Hattori T, et al. Effect of nonuniform muscle contraction on sustainability and frequency of triggered arrhythmias in rat cardiac muscle. Circulation. 2010; 121(25):27112717. [PubMed: 20547931]

155. Ter Keurs HE. Electromechanical coupling in the cardiac myocyte; stretch-arrhythmia feedback. Pflugers Arch. 2011; 462(1):165-175. [PubMed: 21373861]

156. Mehta A, Chung YY, Ng A, et al. Pharmacological response of human cardiomyocytes derived from virus-free induced pluripotent stem cells. Cardiovasc. Res. 2011; 91(4):577-586. [PubMed: 21565833]

157. Papapetrou EP, Sadelain M. Generation of transgene-free human induced pluripotent stem cells with an excisable single polycistronic vector. Nat. Protoc. 2011; 6(9):1251-1273. [PubMed: 21886095]

158. Tsutsui H, Valamehr B, Hindoyan A, et al. An optimized small molecule inhibitor cocktail supports long-term maintenance of human embryonic stem cells. Nat. Commun. 2011; 2:167. [PubMed: 21266967]

159. Chi JT, Chang HY, Haraldsen G, et al. Endothelial cell diversity revealed by global expression profiling. Proc. Natl Acad. Sci. USA. 2003; 100(19):10623-10628. [PubMed: 12963823]

160. Chang HY, Chi JT, Dudoit S, et al. Diversity, topographic differentiation, and positional memory in human fibroblasts. Proc. Natl Acad. Sci. USA. 2002; 99(20):12877-12882. [PubMed: 12297622]

161. Kolossov E, Bostani T, Roell W, et al. Engraftment of engineered ES cell-derived cardiomyocytes but not BM cells restores contractile function to the infarcted myocardium. J. Exp. Med. 2006; 203(10):2315-2327. [PubMed: 16954371]

162. Limpitikul W, Christoforou N, Thompson SA, Gearhart JD, Tung L, Lipke EA. Influence of electromechanical activity on cardiac differentiation of mouse embryonic stem cells. Cardiovasc. Eng. Technol. 2010; 1(3):179-193.

163. Moretti A, Bellin M, Jung CB, et al. Mouse and human induced pluripotent stem cells as a source for multipotent Isl1 ${ }^{+}$cardiovascular progenitors. FASEB J. 2010; 24(3):700-711. [PubMed: 19850773]

164. Kattman SJ, Huber TL, Keller GM. Multipotent Flk-1 ${ }^{+}$cardiovascular progenitor cells give rise to the cardiomyocyte, endothelial, and vascular smooth muscle lineages. Dev. Cell. 2006; 11(5): 723-732. [PubMed: 17084363]

165. Kim YY, Ku SY, Liu HC, et al. Cryopreservation of human embryonic stem cells derivedcardiomyocytes induced by BMP2 in serum-free condition. Reprod. Sci. 2011; 18(3):252-260. [PubMed: 21266662] 
166. Sumi T, Tsuneyoshi N, Nakatsuji N, Suemori H. Defining early lineage specification of human embryonic stem cells by the orchestrated balance of canonical Wnt/beta-catenin, activin/nodal and BMP signaling. Development. 2008; 135(17):2969-2979. [PubMed: 18667462]

167. Hao J, Daleo MA, Murphy CK, et al. Dorsomorphin, a selective small molecule inhibitor of BMP signaling, promotes cardiomyogenesis in embryonic stem cells. PLoS One. 2008; 3(8):E2904. [PubMed: 18682835]

168. Ao A, Williams CH, Hao J, Hong CC. Modified mouse embryonic stem cell based assay for quantifying cardiogenic induction efficiency. J. Vis. Exp. 2011; (50):2656. [PubMed: 21540823]

169. Campa VM, Gutiérrez-Lanza R, Cerignoli F, et al. Notch activates cell cycle reentry and progression in quiescent cardiomyocytes. J. Cell. Biol. 2008; 183(1):129-141. [PubMed: 18838555]

170. Wang H, Hao J, Hong CC. Cardiac induction of embryonic stem cells by a small molecule inhibitor of Wnt/ $\beta$-catenin signaling. ACS Chem. Biol. 2011; 6(2):192-197. [PubMed: 21077691]

171. Wobus AM, Kaomei G, Shan J, et al. Retinoic acid accelerates embryonic stem cell-derived cardiac differentiation and enhances development of ventricular cardiomyocytes. J. Mol. Cell. Cardiol. 1997; 29(6):1525-1539. [PubMed: 9220339]

172. Zhang Q, Jiang J, Han P, et al. Direct differentiation of atrial and ventricular myocytes from human embryonic stem cells by alternating retinoid signals. Cell Res. 2011; 21(4):579-587. [PubMed: 21102549]

173. Lin SC, Dollé P, Ryckebüsch L, et al. Endogenous retinoic acid regulates cardiac progenitor differentiation. Proc. Natl Acad. Sci. USA. 2010; 107(20):9234-9239. [PubMed: 20439714]

174. Jang J, Ku SY, Kim JE, et al. Notch inhibition promotes human embryonic stem cell-derived cardiac mesoderm differentiation. Stem Cells. 2008; 26(11):2782-2790. [PubMed: 18757302]

175. Chan SS, Li HJ, Hsueh YC, et al. Fibroblast growth factor-10 promotes cardiomyocyte differentiation from embryonic and induced pluripotent stem cells. PLoS One. 2010; 5(12):E14414. [PubMed: 21203390]

176. Vega-Hernandez M, Kovacs A, De Langhe S, Ornitz DM. FGF10/FGFR2b signaling is essential for cardiac fibroblast development and growth of the myocardium. Development. 2011; 138(15): 3331-3340. [PubMed: 21750042]

177. Yook JY, Kim MJ, Son MJ, et al. Combinatorial activin receptor-like kinase/Smad and basic fibroblast growth factor signals stimulate the differentiation of human embryonic stem cells into the cardiac lineage. Stem Cells Dev. 2011; 20:1479-1490. [PubMed: 21208046]

178. Kleger A, Seufferlein T, Malan D, et al. Modulation of calcium-activated potassium channels induces cardiogenesis of pluripotent stem cells and enrichment of pacemaker-like cells. Circulation. 2010; 122:1823-1836. [PubMed: 20956206]

179. Anversa P, Olivetti G, Loud AV. Morphometric study of early postnatal development in the left and right ventricular myocardium of the rat. I. Hypertrophy, hyperplasia, and binucleation of myocytes. Circ. Res. 1980; 46(4):495-502. [PubMed: 6444554]

180. Hirota A, Kamino K, Komuro H, Sakai T, Yada T. Early events in development of electrical activity and contraction in embryonic rat heart assessed by optical recording. J. Physiol. 1985; 369:209-227. [PubMed: 4093880]

181. Yasui K, Liu W, Opthof T, et al. I(f) current and spontaneous activity in mouse embryonic ventricular myocytes. Circ. Res. 2001; 88:536-542. [PubMed: 11249878]

182. Siedner S, Kruger M, Schroeter M, et al. Developmental changes in contractility and sarcomeric proteins from the early embryonic to the adult stage in the mouse heart. J. Physiol. 2003; 548(Pt 2):493-505. [PubMed: 12640016]

183. Vaidya D, Tamaddon HS, Lo CW, et al. Null mutation of connexin 43 causes slow propagation of ventricular activation in the late stages of mouse embryonic development. Circ. Res. 2001; 88:1196-1202. [PubMed: 11397787]

184. Liu A, Tang M, Xi J, et al. Functional characterization of inward rectifier potassium ion channel in murine fetal ventricular cardiomyocytes. Cell. Physiol. Biochem. 2010; 26:413-420. [PubMed: 20798526] 
185. Thomas SP, Bircher-Lehmann L, Thomas SA, Zhuang J, Saffitz JE, Kleber AG. Synthetic strands of neonatal mouse cardiac myocytes: structural and electrophysiological properties. Circ. Res. 2000; 87(6):467-473. [PubMed: 10988238]

186. Nuss HB, Marban E. Electrophysiological properties of neonatal mouse cardiac myocytes in primary culture. J. Physiol. 1994; 479(Pt 2):265-279. [PubMed: 7799226]

187. Guerrero PA, Schuessler RB, Davis LM, et al. Slow ventricular conduction in mice heterozygous for a connexin43 null mutation. J. Clin. Invest. 1997; 99:1991-1998. [PubMed: 9109444]

188. Wang L, Feng ZP, Kondo CS, Sheldon RS, Duff HJ. Developmental changes in the delayed rectifier $\mathrm{K}^{+}$channels in mouse heart. Circ. Res. 1996; 79(1):79-85. [PubMed: 8925572]

189. Fiset C, Clark RB, Larsen TS, Giles WR. A rapidly activating sustained $\mathrm{K}^{+}$current modulates repolarization and excitation-contraction coupling in adult mouse ventricle. J. Physiol. 1997; 504(Pt 3):557-563. [PubMed: 9401964]

\section{Website}

201. NIH. Registry and results database of federally and privately supported clinical trials conducted in the USA and around the world. 2011. http://clinicaltrials.gov 


\section{Executive summary}

\section{Background of cell-based cardiac therapies}

- Cell-based cardiac therapies are aimed at replacing tissue that is lost during myocardial infarction.

- Low retention and survival of injected cells is the main obstacle to more successful cardiac therapies. Currently, injected adult stem cells in clinics mainly exert their effects through paracrine action, as they cannot efficiently differentiate into functional cardiomyocytes.

- Implanted engineered tissue patches have been shown to be superior to cell injections in several animal studies.

Current state of pluripotent stem cell-based cardiac tissue engineering

- Pluripotent (induced and embryonic) stem cells can robustly differentiate into functional cardiomyocytes and, in theory, generate large cell quantities necessary for tissue-engineering therapies.

- Although mouse and human cells require different conditions for the maintenance of pluripotency, they can be differentiated into a cardiac fate using similar techniques.

- General methods to efficiently differentiate and purify human pluripotent stem cell-derived cardiomyocytes do not exist. Optimal methods need to be redefined for each cell line.

- Mouse and human pluripotent stem cell-derived cardiomyocytes have been combined with scaffolding materials in different geometries to form engineered tissue patches. Addition of different stromal cells in the patch supports cell survival and tissue formation, but the underlying mechanisms are unknown.

- Tissue patch contractile forces of up to $2 \mathrm{mN}$ and action potential conduction velocities of up to $25 \mathrm{~cm} / \mathrm{s}$ have been reported. Patches implanted in infarcted rodent hearts have been shown to integrate with host vasculature.

Structural \& functional assessment of stem cell-derived cardiomyocytes \& cardiac tissues

- Electrophysiological function assessment methods: patch clamps, sharp microelectrode recordings, multielectrode arrays and optical mapping using voltage- and calcium-sensitive dyes.

- Mechanical function assessment methods: passive tension and active contractile force measurement using force transducers or indirect measurement using elastic bending theory.

- Synchronous contractions are not a suitable method to assess functional cell coupling, and video edge detection is not a suitable method to quantify contractile force generation.

- Assessment of the structural and functional maturity of stem cell-derived cardiomyocytes and cardiac tissues should be based on the existing knowledge from embryonic and postnatal cardiac development.

- Assessment of ultrastructural properties: cell dimensions and shape, gap and mechanical junction types and distribution, cytoskeletal proteins, T-tubules and couplons and mitochondrial content. 
Assessment of electrophysiological properties: maximum diastolic potential, action potential duration, maximum upstroke velocity, conduction velocity and maximum capture rate.

Assessment of excitation-contraction coupling properties: colocalization of sarcolemmal $\mathrm{Ca}^{2+}$ channels and ryanodine receptors, expression of $\mathrm{Ca}^{2+}$ buffering proteins, $\mathrm{Ca}^{2+}$ transient shape and amplitude and contribution of sarcoplasmic $\mathrm{Ca}^{2+}$ release to $\mathrm{Ca}^{2+}$ transients.

Assessment of mechanical properties: passive and contractile stress measured by a near-threshold point stimulus, force-frequency and force-length relationships and force sensitivity to extracellular $\mathrm{Ca}^{2+}$. 


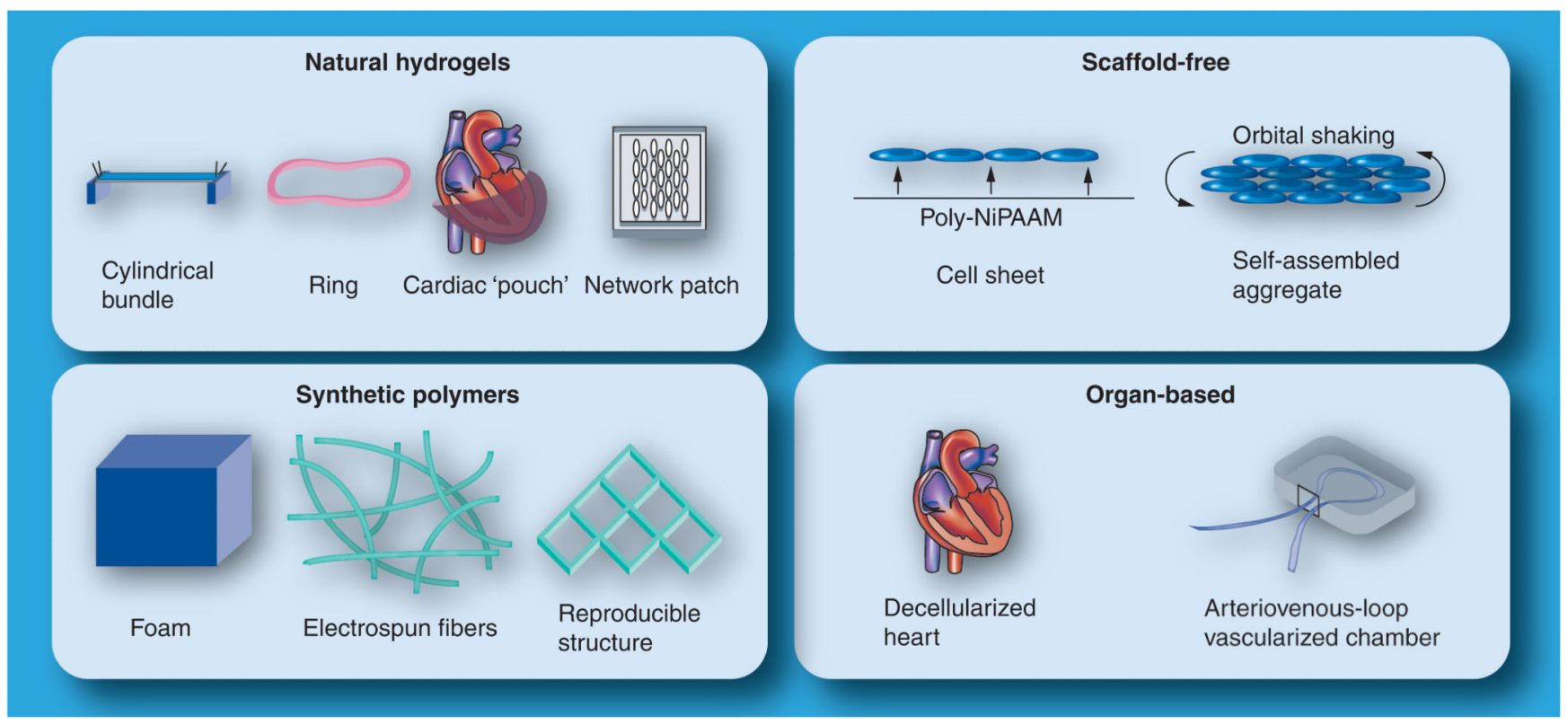

Figure 1.

Cardiac tissue-engineering approaches. 
Table 1

Derivation and selection of stem cell-derived cardiomyocytes and cardiovascular progenitors

\begin{tabular}{|c|c|c|c|c|}
\hline $\begin{array}{l}\text { Promoter or } \\
\text { marker used }\end{array}$ & $\begin{array}{l}\text { Selection } \\
\text { method }\end{array}$ & Classification & Cell source & Ref. \\
\hline $\mathrm{a}-\mathrm{MHC}$ & Antibiotic, FACS & $\begin{array}{l}\text { Nodal, atrial and ventricular } \\
\text { cardiomyocytes }\end{array}$ & mESC, hESC & {$[82,161,162]$} \\
\hline MLC-2V & Antibiotic, FACS & Ventricular cardiomyocytes & mESC, hESC & {$[69,82]$} \\
\hline Nkx2.5 & Antibiotic, FACS & Cardiovascular progenitors & mESC, miPSC & {$[66,108]$} \\
\hline Isl-1 & FACS & Cardiovascular progenitors & mESC, hESC & {$[131,163]$} \\
\hline NCX-1 & Antibiotic & $\begin{array}{l}\text { Atrial and ventricular } \\
\text { cardiomyocytes }\end{array}$ & $\mathrm{mESC}$ & [72] \\
\hline KDR/Flk-1 & FACS & Cardiovascular progenitors & mESC, hESC & {$[40,164]$} \\
\hline SSEA-1 & FACS & Cardiovascular progenitors & hESC, primate ESC & [86] \\
\hline Mitochondrial dye & FACS & Cardiomyocytes & $\mathrm{mESC}$ & {$[76]$} \\
\hline
\end{tabular}

ESC: Embryonic stem cell; FACS: Fluorescence-activated cell sorting; hESC: Human embryonic stem cell; mESC: Mouse embryonic stem cell; miPSC: Mouse induced pluripotent stem cell. 


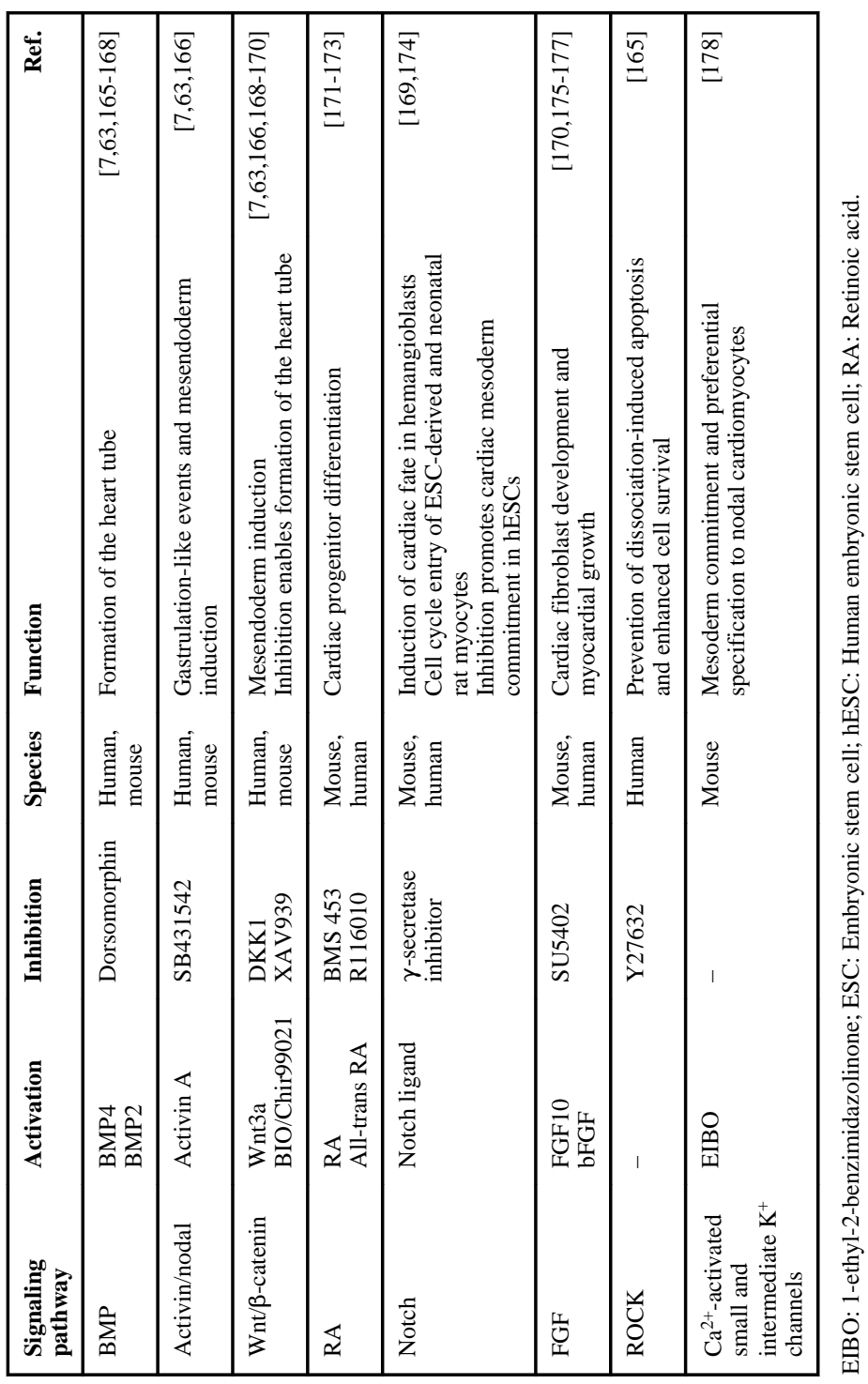

Regen Med. Author manuscript; available in PMC 2013 April 04. 
Table 3

Functional cardiac tissue engineering using pluripotent stem cells

\begin{tabular}{|c|c|c|c|c|}
\hline Cell type/population & Cell purification & Methodology & Functional test & Ref. \\
\hline mESC cardiomyocytes & $\begin{array}{l}\text { Percoll gradient } \\
\text { centrifugation }\end{array}$ & 1D collagen EHT bundle & Twitch contractile force & [68] \\
\hline $\begin{array}{l}\text { hESC cardiomyocytes, HUVECs } \\
\text { and mouse embryonic fibroblasts }\end{array}$ & Microdissection & $\begin{array}{l}\text { Seeding onto porous collagen } \\
\text { foam }\end{array}$ & $\begin{array}{l}\text { Synchronous contractions and } \\
\text { calcium transient imaging }\end{array}$ & [91] \\
\hline $\begin{array}{l}\text { hESC cardiomyocytes, HUVECs } \\
\text { and mouse embryonic fibroblasts }\end{array}$ & $\begin{array}{l}\text { Directed } \\
\text { differentiation }\end{array}$ & Orbital shaking self-aggregation & $\begin{array}{l}\text { In vitro electrical pacing, passive } \\
\text { mechanical properties, in vivo } \\
\text { implantation }\end{array}$ & [96] \\
\hline $\mathrm{mESC}$ cardiovascular progenitors & $\begin{array}{l}\text { FACS sorting of } \\
\text { Isl- } 1^{+} \text {cells }\end{array}$ & $\begin{array}{l}\text { Seeding on 2D micropatterned } \\
\text { PDMS substrates }\end{array}$ & $\begin{array}{l}\text { Curvature-based contractile strain } \\
\text { assay }\end{array}$ & [131] \\
\hline $\begin{array}{l}\text { hESC and hiPSC cardiomyocytes, } \\
\text { HUVECs, human marrow stromal } \\
\text { cells and mouse embryonic } \\
\text { fibroblasts }\end{array}$ & $\begin{array}{l}\text { Percoll gradient } \\
\text { centrifugation or } \\
\text { none }\end{array}$ & 1D collagen EHT bundle & $\begin{array}{l}\text { Twitch contractile force, in vivo } \\
\text { implantation }\end{array}$ & [78] \\
\hline mESC cardiomyocytes & Antibiotic selection & 1D collagen EHT bundle & None & [60] \\
\hline $\begin{array}{l}\text { mESC cardiomyocytes and } \\
\text { cardiovascular progenitors }\end{array}$ & Antibiotic selection & 3D fibrin network & $\begin{array}{l}\text { Conduction velocity and twitch } \\
\text { contractile force }\end{array}$ & [89] \\
\hline mESC cardiomyocytes & Antibiotic selection & $2 \mathrm{D}$ cell sheet & $\begin{array}{l}\text { Unidirectional action potential } \\
\text { propagation, coupling with } \\
\text { neighboring cell sheet }\end{array}$ & [97] \\
\hline
\end{tabular}

EHT: Engineered heart tissue; FACS: Fluorescence-activated cell sorting; hESC: Human embryonic stem cell; hiPSC: Human induced pluripotent stem cell; HUVEC: Human vascular endothelial cell; mESC: Mouse embryonic stem cell; PDMS: Polydimethylsiloxane. 
Table 4

\section{Structural and functional changes during rodent cardiac development}

\begin{tabular}{|c|c|c|c|}
\hline Stage & Time & Structure & Function \\
\hline $\begin{array}{l}\text { Early embryonic } \\
\text { (tubular heart) }\end{array}$ & $\begin{array}{l}\text { E8.5-E11 } \\
\text { (mouse) } \\
\text { E10-E12 (rat) }\end{array}$ & $\begin{array}{l}\text { Round to polygonal cell shape }[41,137] \\
\text { Irregular myofilament arrangement [137] } \\
\text { Adherens junctions and desmosomes are } \\
\text { uniformly distributed in } \\
\text { cell membrane }[140,142] \\
\text { Formation of nascent } \mathrm{Z} \text { discs [141] } \\
\text { Cardiomyocytes are mainly } \\
\text { mononucleated until after birth [179] }\end{array}$ & $\begin{array}{l}\text { Connexin- } 45 \text { is weakly expressed in all cardiac } \\
\text { compartments [139] } \\
\text { Low conduction velocity }(0.8 \mathrm{~mm} / \mathrm{s} \text { in rat heart tube) [180] } \\
\text { Low }(\mathrm{dV} / \mathrm{dt})_{\max }^{+}(88.2 \mathrm{~V} / \mathrm{s} \text { in } \mathrm{E} 9.5 \text { mouse ventricular cells }) \\
{[181]} \\
\text { Long action potential duration }\left(\mathrm{APD}_{50}=100-200 \mathrm{~ms} \text { in }\right. \\
\text { E9.5 mouse) [72] } \\
\text { Low contractile stress }(0.36 \mathrm{mN} / \mathrm{mm} 2 \text { in E10.5 mouse } \\
\text { cardiomyocytes) [182] }\end{array}$ \\
\hline $\begin{array}{l}\text { Late embryonic/ } \\
\text { fetal (looping/ } \\
\text { segmentation) }\end{array}$ & $\begin{array}{l}\text { E11-birth } \\
\text { (mouse) } \\
\text { E12-birth (rat) }\end{array}$ & $\begin{array}{l}\text { Nascent T-tubules are formed as minor } \\
\text { sarcolemmal } \\
\text { invaginations [41,137] } \\
\text { Myofilaments arrange into long, compact } \\
\text { and well-organized } \\
\text { myofibrils [137] } \\
\text { Adherens junctions and desmosomes } \\
\text { localize to myofibril } \\
\text { attachment sites [140,142] } \\
\text { Development of I and A bands [141] } \\
\text { Well-defined Z discs form [141] }\end{array}$ & $\begin{array}{l}\text { Downregulation of connexin- } 45 \text { [139] } \\
\text { Initiation and increase of uniform connexin- } 40 \text { and }-43 \\
\text { expression in } \\
\text { cell membrane [138] } \\
\text { Conduction velocity increases }(7-21 \mathrm{~cm} / \mathrm{s} \text { in mouse } \\
\text { ventricles) }[183] \\
(\mathrm{dV} / \mathrm{dt})_{\max }^{+} \text {increases }(113.2 \mathrm{~V} / \mathrm{s} \text { in } \mathrm{E} 18.5 \text { mouse } \\
\text { ventricular cells) [181] } \\
\text { Action potential duration shortens }\left(\mathrm{APD}_{50}=74 \mathrm{~ms} \text { in E18 }\right. \\
\text { mouse) }[72,184] \\
\text { Contractile stress increases }(0.91-1.8 \mathrm{mN} / \mathrm{mm} 2 \text { in E13.5- } \\
19.5 \text { mouse } \\
\text { cardiomyocytes) }[179]\end{array}$ \\
\hline Neonatal & Birth-D15 & $\begin{array}{l}\text { Rod cell shape [179] } \\
\text { Adherens junctions and desmosomes start } \\
\text { to move to cell ends } \\
\text { and localize in intercalated discs } \\
{[137,140-142]} \\
\text { Functional couplons start to form }[41,143] \\
48 \% \text { of cardiomyocytes are binucleated at } \\
\text { D11 [179] }\end{array}$ & $\begin{array}{l}\text { Downregulation of connexin- } 40 \text { [140] } \\
\text { Punctate expression of connexin- } 43 \text { gap junctions in cell } \\
\text { membrane [142] } \\
\text { Initiation of Ca } \mathrm{Ca}^{2+} \text { sparking [143] } \\
\text { Conduction velocity increases }(24-29 \mathrm{~cm} / \mathrm{s} \text { in mouse } \\
\text { ventricles) [183] } \\
(\mathrm{dV} / \mathrm{dt})_{\max }{ }^{\dagger} \text { increases }(196 \mathrm{~V} / \mathrm{s} \text { in neonatal mouse) }[185] \\
\text { Action potential duration shortens }\left(\mathrm{APD}_{50}=23 \mathrm{~ms} \text { and }\right. \\
\mathrm{APD}_{90}=42 \mathrm{~ms} \\
\text { in neonatal mouse) [186] } \\
\text { Contractile stress increases }\left(3.1 \mathrm{mN} / \mathrm{mm}^{2} \text { in D7 mouse }\right. \\
\text { cardiomyocytes) [182] }\end{array}$ \\
\hline Adult & D15 onwards & $\begin{array}{l}\text { Mature T-tubules form as deep membrane } \\
\text { invaginations into } \\
\text { cytoplasm [143] } \\
\text { Colocalization of ryanodine receptors and } \\
\mathrm{Ca}^{2+} \text { channels [143] } \\
\text { Fully mature intercalated discs are formed } \\
{[142]} \\
\text { Cardiomyocytes are mainly binucleated } \\
{[179]}\end{array}$ & $\begin{array}{l}\text { Connexin- } 43 \text { gap junctions move to intercalated discs } \\
{[138,142]} \\
\text { High conduction velocity }(30-45 \mathrm{~cm} / \mathrm{s})[187] \\
(\mathrm{dV} / \mathrm{dt})_{\max }{ }^{\dagger} \text { is maximum }(221 \mathrm{~V} / \mathrm{s} \text { in adult mouse) [188] } \\
\text { Action potential duration is short }\left(\mathrm{APD}_{50}=6 \mathrm{~ms} \text { and }\right. \\
\mathrm{APD}_{90}=20.7 \mathrm{~ms} \\
\text { in adult mouse })[189] \\
\text { Contractile stress is maximum }(6-8 \mathrm{mN} / \mathrm{mm} 2 \text { in } 6-8 \text {-week- } \\
\text { old adult } \\
\text { mouse) }[182]\end{array}$ \\
\hline
\end{tabular}

APD50: Action potential duration at 50\% repolarization; APD90: Action potential duration at 90\% repolarization; D: Day; E: Embryonic day.

${ }^{\dagger}$ Maximum rate of action potential rise. 